\title{
The Places of Memory in a Square of Monuments: Conceptions of Past, Freedom and History at Szabadság Tér
}

Erik Thorstensen, The Center for Studies of Holocaust and Religious Minorities, Norway

\begin{abstract}
In this paper I try to approach contemporary Hungarian political culture through an analysis of the history of changing monuments at Szabadság Tér in Budapest. The paper has as its point of origin a protest/irredentist monument facing the present Soviet liberation monument. In order to understand this irredentist monument, I look into the meaning of the earlier irredentist monuments under Horthy and try to see what monuments were torn down under Communism and which ones remained. I further argue that changes in the other monuments also affect the meaning of the others. From this background I enter into a brief interpretation of changes in memory culture in relation to changes in political culture. The conclusions point toward the fact that Hungary is actively pursuing a cleansing of its past in public spaces, and that this process is reflected in an increased acceptance of political authoritarianism.
\end{abstract}

Keywords: monuments, Budapest, irredentism, memory, public spaces

Biography: Erik Thorstensen has been an educator at the Center for Studies of Holocaust and Religious Minorities, Norway, since 2005. Previously he did research in ethics and lectured in history of religions at the University of Oslo. He was co-editor of Historicizing the Uses of the Past: Scandinavian Perspectives on History Culture, Historical Consciousness and Didactics of History Related to World War II, published in 2011. He has previously published in history of religions, ethics, cultural studies, and literature. In 2012 he will publish a monograph on naturalistic atheism and its relations to politics.

The background for this study is a visit to Budapest in the spring of 2008. The purpose was to study Hungarian memory culture in relation to the Holocaust. When entering Szabadság tér (Freedom Square) I was struck by a grey tent-like structure directly opposite to the monument raised to commemorate the liberation of Budapest by the Soviet Red Army in 1945. In front of this grey tent there were three large wooden crosses. The tent structure had several written messages that all demanded the removal of the Soviet Red Army monument and the restoration of a monument that had previously been in its place.

The purpose of this paper is to try to reflect on the whole monument complex at Szabadság tér as it presented itself to a visitor in the spring 2008. I will use these thoughts to try to grasp some of the basic ideas behind political memories and to follow recent developments in Hungarian political culture. 
Erik Thorstensen. "The Places of Memory in a Square of Monuments: Conceptions of Past, Freedom and History at Szabadság Tér. AHEA: E-journal of the American Hungarian Educators Association, Volume 5 (2012): http://ahea.net/e-journal/volume-52012

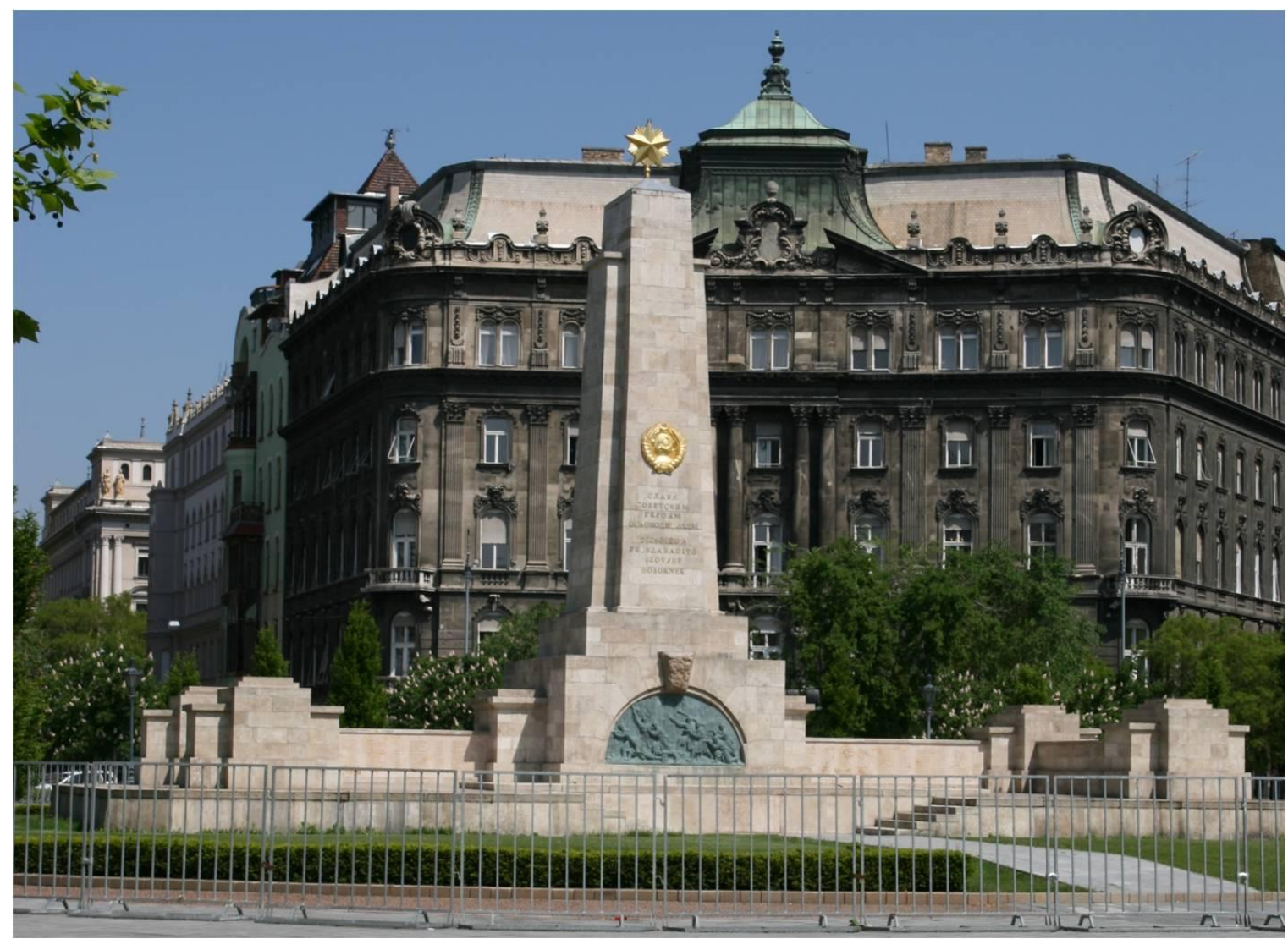

Fig. 1 The Soviet Liberation Monument. Source: Photo by author, (C) Erik Thorstensen

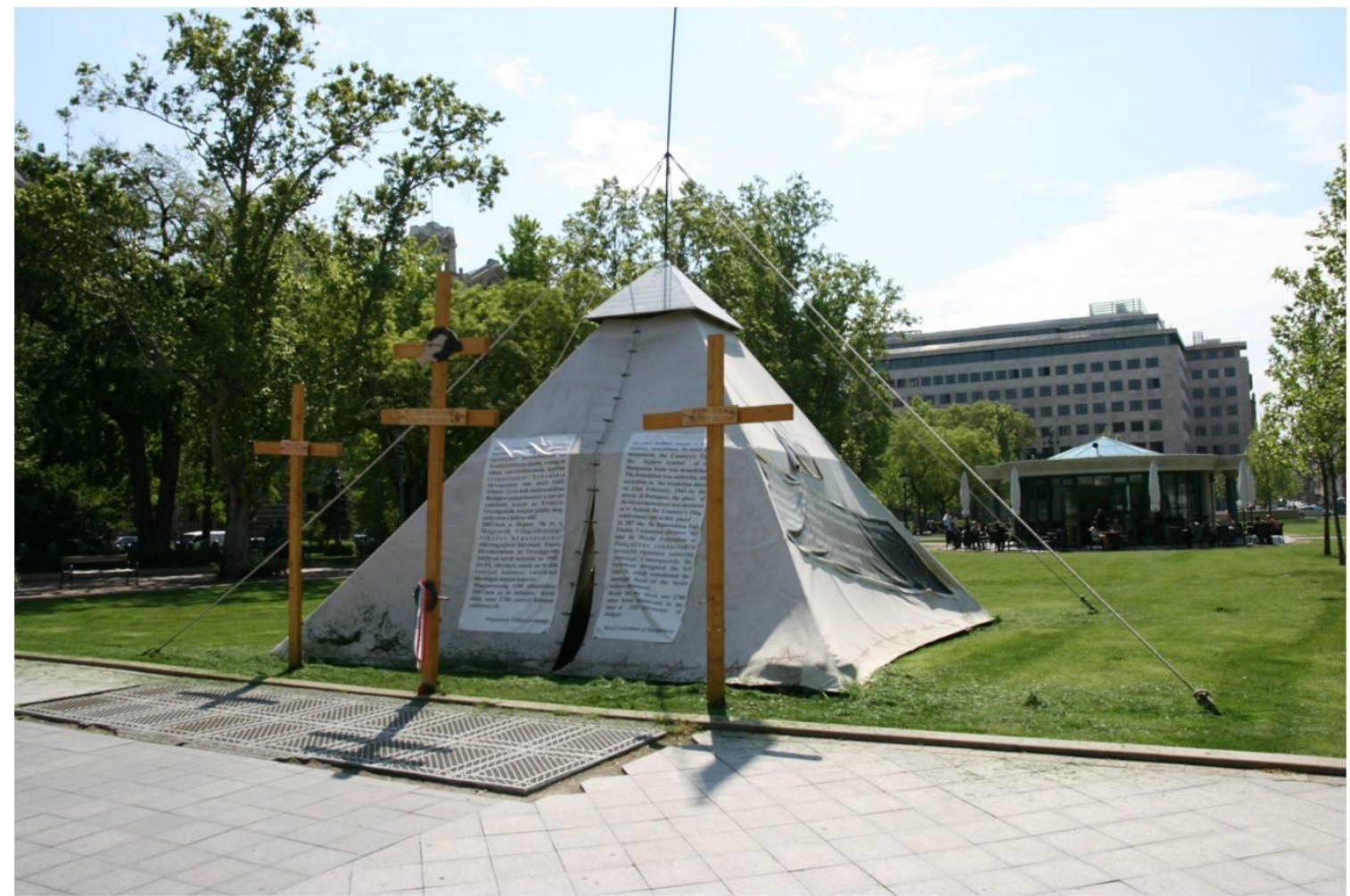

Fig. 2 Protest Monument against the Soviet Liberation Monument. Source: Photo by author. (C) Erik Thorstensen. 
Erik Thorstensen. "The Places of Memory in a Square of Monuments: Conceptions of Past, Freedom and History at Szabadság Tér. AHEA: E-journal of the American Hungarian Educators Association, Volume 5 (2012): http://ahea.net/e-journal/volume-52012

In order to present my argument and analysis, I need to place Budapest and the developments in local political culture within a larger Western framework. A striking will to create grandeur was a feature in American and European city planning in the latter nineteenth century, where Hausmann's Paris and the Wiener Ringstrasse are but two examples of imposing and beautiful boulevards, parks, and squares (Hall 2002, 189). Budapest is no exception.

Imprinted in Budapest's cityscape are some important buildings, structures, and monuments. Many of these are connected to the political emancipations following the Compromise with Austria in 1867 and signal a growing national independence. The most impressive and eye-catching is the Hungarian Parliament building - the Országház - built on the model of Westminster in London. Its English model was built between 1840 and 1860 by Charles Barry (Hunt 83). Its Neo-Gothic style symbolized the early Saxon political community which was popular in the Romantic architecture. The Hungarian political elite imagined the British Magna Carta (1215) to be the equivalent to their Golden Bull (1222), and saw both legal documents as the foundation for the political community. The ideal of independent democracy expressed in Neo-Gothic resonated well with the Hungarians, and therefore the Országház became a Neo-Gothic building (Gerö 1997, 26). The institution in charge of selecting the winner amongst the architects' proposals justified the choice of Imre Steindl's plans with the words:

The building must be ornamental and monumental not only for artistic and architectural reasons, but it must be large, ornamental and monumental for national reasons, and because for the stated reasons, the Committee considers it essential that the building be endowed with the monumental nature of the present era (Gerö 1997, 21-2)

The reasons stated here can be used to formulate some general insights about how monuments function and why monuments are built. Current theories in cultural history see monuments as an exteriorization of memory (Nora 1989; Savage 1994; Young 1992). There is an inherent contradiction here: If the event really is/was so important, why is it then necessary to erect a stone in order to remember it?

In a condensed form, David Atkinson and Dennis Cosgrove $(1998,30)$ have summed up the function of public monuments - in particular those "intended to encapsulate an imagined national spirit or identity" as structures or spaces that "seek to materialize ideas of the sacred, the mystical, and the transcedental". This commemorative function is, however, only one part of the monument's importance. In addition to its referring to one (or several) events in the past, it must also seek to remind present and future visitors about the significance of these past events. The constructors/sponsors wish to communicate to coming generations the importance of both the memorialized event and its naturalized connection to the society's past. As a contemporary visitor, this relation to the past will for me be both the past event that the monument is referring to and the past event of erecting the monument. The first relation is present through the meaning of the monument and the second through the materiality of the monument. There are three temporal dimensions involved in the monuments at the Szabadság tér: the past event, the significance and interpretation of the past event, and the material construction and re-construction of the monuments themselves.

The builders of monuments have no way of gazing into the future. This point can be illustrated by The Millennium Monument erected in 1896 at Heroes' Square (Hösök tere) in commemoration of twelve Hungarian heroes of the millennium since the first Hungarian kingdom. Of the original twelve statues that were installed, only two remain in their original place - St. Stephen and King Árpád (Lendvai 2003, 311). There has been a substantial coming and going of heroes, mainly due to two factors: an exceptionally long period of construction (1893-1929) and changing political regimes (Gerö 2006, 173-212). The first statue ready to be installed in 1897 was the Archangel Michael. However, it was not put in its place at the center column until 1910 because of construction errors, and was subsequently removed during the Commune in 1919 because of Communism's inherent atheism. The Commune also removed all monuments of the Habsburg monarchs, but they were reinstalled during the early 1920s (Gerö 1990, 19-24). After the Second World War, history repeated itself when once again the Habsburg monarchs were removed, but this time 
Erik Thorstensen. "The Places of Memory in a Square of Monuments: Conceptions of Past, Freedom and History at Szabadság Tér. AHEA: E-journal of the American Hungarian Educators Association, Volume 5 (2012): http://ahea.net/e-journal/volume-52012

they were replaced with other persons: Ferdinand I was replaced by István Bocskai; Charles III by Gábor Bethlen; Maria Theresa by Imre Thököly; Leopold II by Ferenc Rákóczi; and Francis Joseph by Lajos Kossuth. Engravings depicting Hungarian national expansion were also removed (Gerő 1990, 30-33).

Heroes' Square (Hösök tere) is a good example illustrating Emilia Palonen's point that renaming and statue removals is a Hungarian tradition. In the 1930s and 1940s the squares located on the Andrassy boulevard were renamed after Hitler and Mussolini (Palonen 2006, 233), and then under Communism they were given leading communist names. Heroes' Square (Hösök tere) got its present name in 1932 (Gerö 2006, 206). This form of Damnatio memoriae, "the eradication of visual representations of the person, a ban of the name, and a prohibition of the observance of the funeral and mourning" (Hedrick xii), is an ancient custom and the practice was well established in the Roman Empire, and not at all exclusive to Hungary after 1918. But if we accept Michel Foucault's claim that the main purpose of history writing before the late seventeenth century was to legitimize the right and might of the ruler and to intensify the rulers' virtues, and not to display history as a struggle between nations, then the memorialization and/or obliteration of rulers according to national origin creates the image of the past as a struggle between national groups or races and, if we believe that our conceptions of history form our conceptions of the present, an antagonistic and hostile view on present society (Foucault 58). It is this antagonistic and iconoclastic tendency that I will look into at Budapest's Freedom Square (Szabadság tér).

\section{The monuments at Szabadság tér, past and present}

Aleida Assmann distinguishes between two forms of collective memory: "archive" and "canon". By "archive" she means "what in the long run has been neglected, forgotten, excluded, or discarded, but is still deemed worthy and important enough to be preserved in material form", while "canon" is what "is (or ought to be remembered) by the group" (Assmann 2010, 43). A culture's canon can be exemplified by what any given society has chosen and maintains as worthy to preserve and remember. Examples of such types can be school curricula, national holidays, and museums, while examples of tokens of a canon can for the US be on national level be Thanksgiving, Mount Rushmore, and the diverse Oaths of Allegiance. On a regional level in the US examples of canon would be the Puerto Rican Day Parade in New York, the Norsk Høstfest (North America's largest Scandinavian Festival) in Minot, North Dakota, and the Mardi Gras in New Orleans.

A culture's archive, in turn, contains the societal elements that "linger in latency". These are elements not readily accessible or consciously communicated from one generation to the next. Examples of such types can be all statues and monuments that are not part of any civic or religious ritual, entries that are not taken into new editions of encyclopedias, and subjects that are removed from the school curricula.

In analyzing Szabadság tér's history I will use the distinction between "canon" and "archive". The use of this distinction necessitates an analysis both of what is the story told by the different monuments (canon) and the continued or discontinued physical presence (archive) of a monument at Szabadság tér. There were no monuments installed at Szabadság tér before the 1920s. I have found it useful to divide Szabadság tér's into three periods, corresponding to different political regimes:

1) From Horthy's accession to power;

2) from the end of Nazi rule/beginning of Communist rule; and

3) from the fall of Communism/start of democracy.

The removal of a monument indicates a damnatio memoriae whereby both the monument's story and its sponsors ought to be forgotten, but if - as is the case on Szabadság tér - there are several monuments telling different stories from one sponsor, then the case becomes more complex. In such a case the stories told by the removed monuments will be the stories that the removers will seek to obliterate. Whole scale destruction of monuments that were erected by the same sponsors will then point towards an intentional erasing of those sponsors presence in a given society's history. This methodology of dividing the monuments 
Erik Thorstensen. "The Places of Memory in a Square of Monuments: Conceptions of Past, Freedom and History at Szabadság Tér. AHEA: E-journal of the American Hungarian Educators Association, Volume 5 (2012): http://ahea.net/e-journal/volume-52012

into the periods they were erected ought to give an image of the different political regimes to history and to each other - and hopefully some insight into current Hungarian sociopolitical change.

The Square became a symbol in itself for two reasons: it was called "Freedom Square" and it was built on the premises of the Újépület (The New Building), where the prisons and stables of the Austrian military had stood until late 1897 (Egykor.hu 2010). Many rebels from the unsuccessful national revolution in 1848/49 were imprisoned in the Újépület, and Prime Minister Lajos Batthyány was also executed there by Austrian forces on 6 October 1849. The destruction of the Újépület building can be interpreted as the first attempt in removing a past regime from public spaces. In this case the removal of the Habsburgs and simultaneously removing the memory of the defeat in the national revolution in 1849.

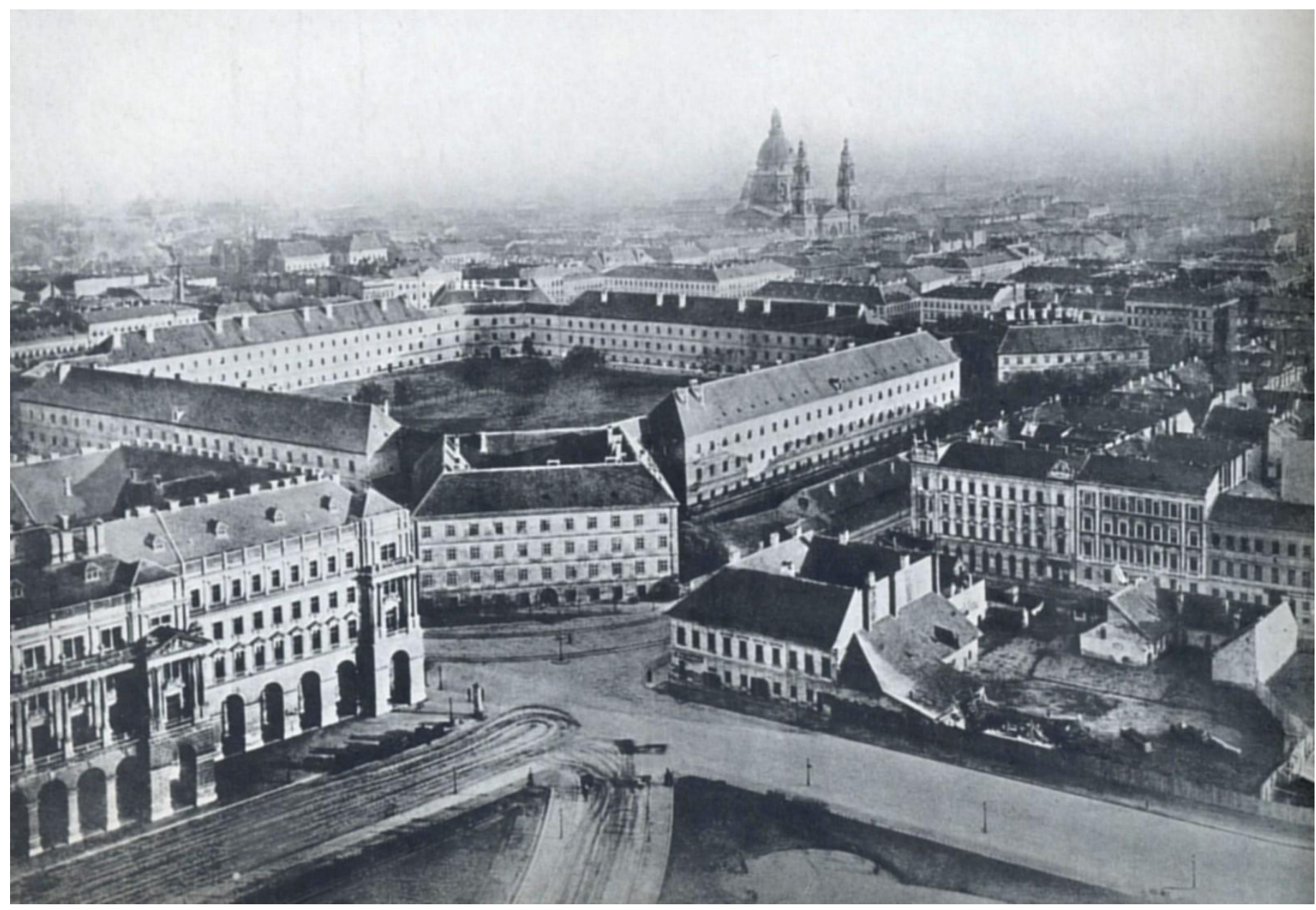

Fig. 3 Újépület in 1895.

Source: http://egykor.hu/images/2010/original/budapest-ujepulet-szabadsag-ter.jpg

However the destruction stands in contrast to twentieth century commemorative practices of turning former detention facilities and places of execution into memorials, with the Auschwitz-Birkenau museum and the former Stasi-prison in Berlin (The Berlin-Hohenschönhausen Memorial) as prime examples. In a Hungarian context, there is also the Terror Háza Museum (House of Terror Museum), the former Arrow Cross headquarters and later Communist prison and torture chamber on Andrássy út 60 in Budapest. 
Erik Thorstensen. "The Places of Memory in a Square of Monuments: Conceptions of Past, Freedom and History at Szabadság Tér. AHEA: E-journal of the American Hungarian Educators Association, Volume 5 (2012): http://ahea.net/e-journal/volume-52012

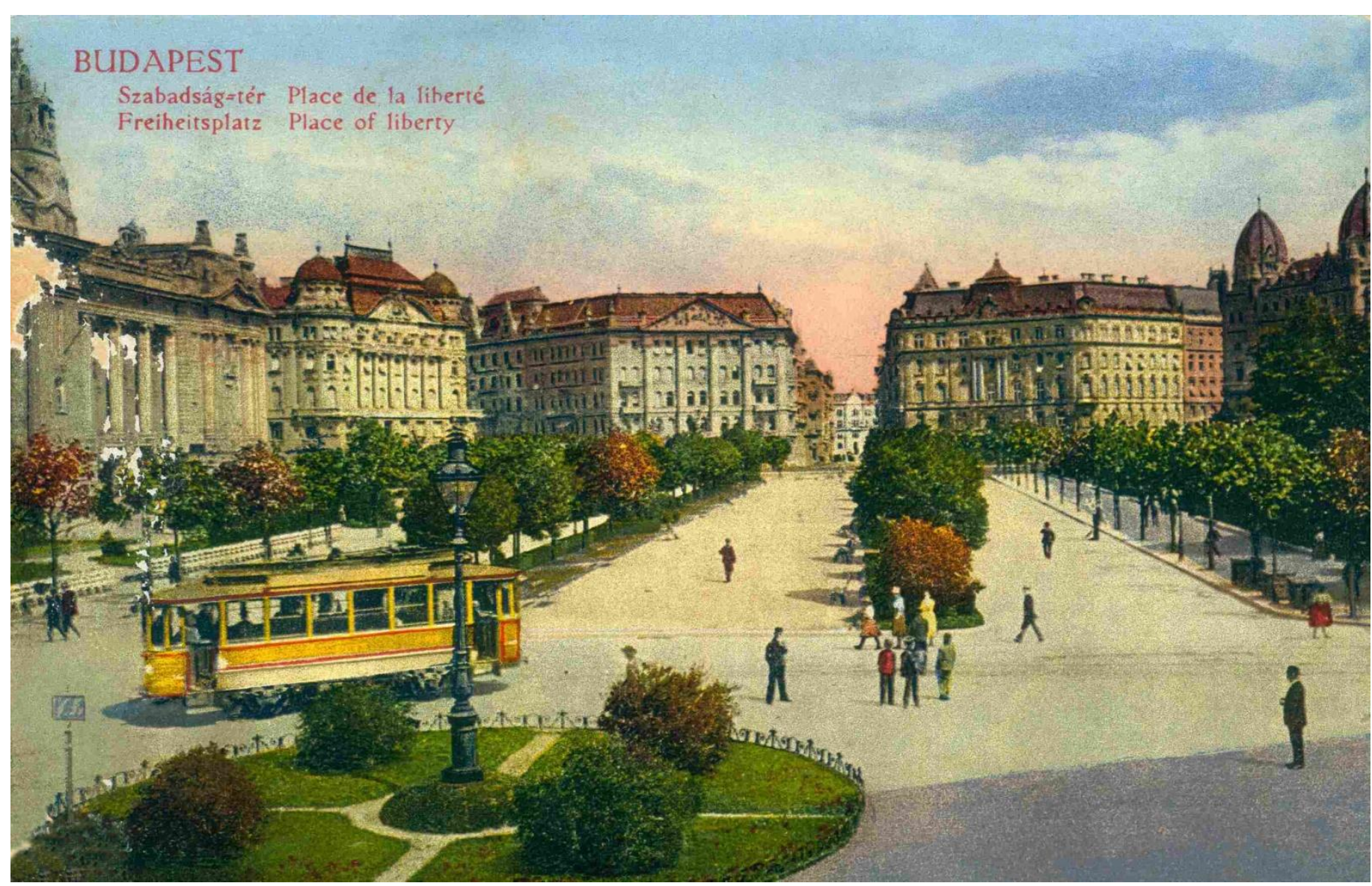

Fig. 4 Szabadság tér in 1912. Source: http://upload.wikimedia.org/wikipedia/commons/1/10/Budapest_Szabadsag_ter_1912.jpg

\section{Szabadság tér during the Horthy period}

Pictures show us a square that is open and unornamented in the period from its finalization to the early years of the Horthy regime. ${ }^{1}$ The first monuments to be erected at Szabadság tér were the so-called "Irredentist Statues" in 1921 symbolizing Hungary's four corners that were perceived as lost as a result of the Treaty of Trianon.

\footnotetext{
${ }^{1}$ Michael Mann (2004, 44-46) classifies the 1920s regimes in Hungary under Horthy and Bethlen as "semi-authoritarian" while the Horthy regime in the 1930s Mann suggests is a "semi-reactionary authoritarian regime". In this paper I will address the Horthy regimes as "authoritarian" tout court.
} 
Erik Thorstensen. "The Places of Memory in a Square of Monuments: Conceptions of Past, Freedom and History at Szabadság Tér. AHEA: E-journal of the American Hungarian Educators Association, Volume 5 (2012): http://ahea.net/e-journal/volume-52012
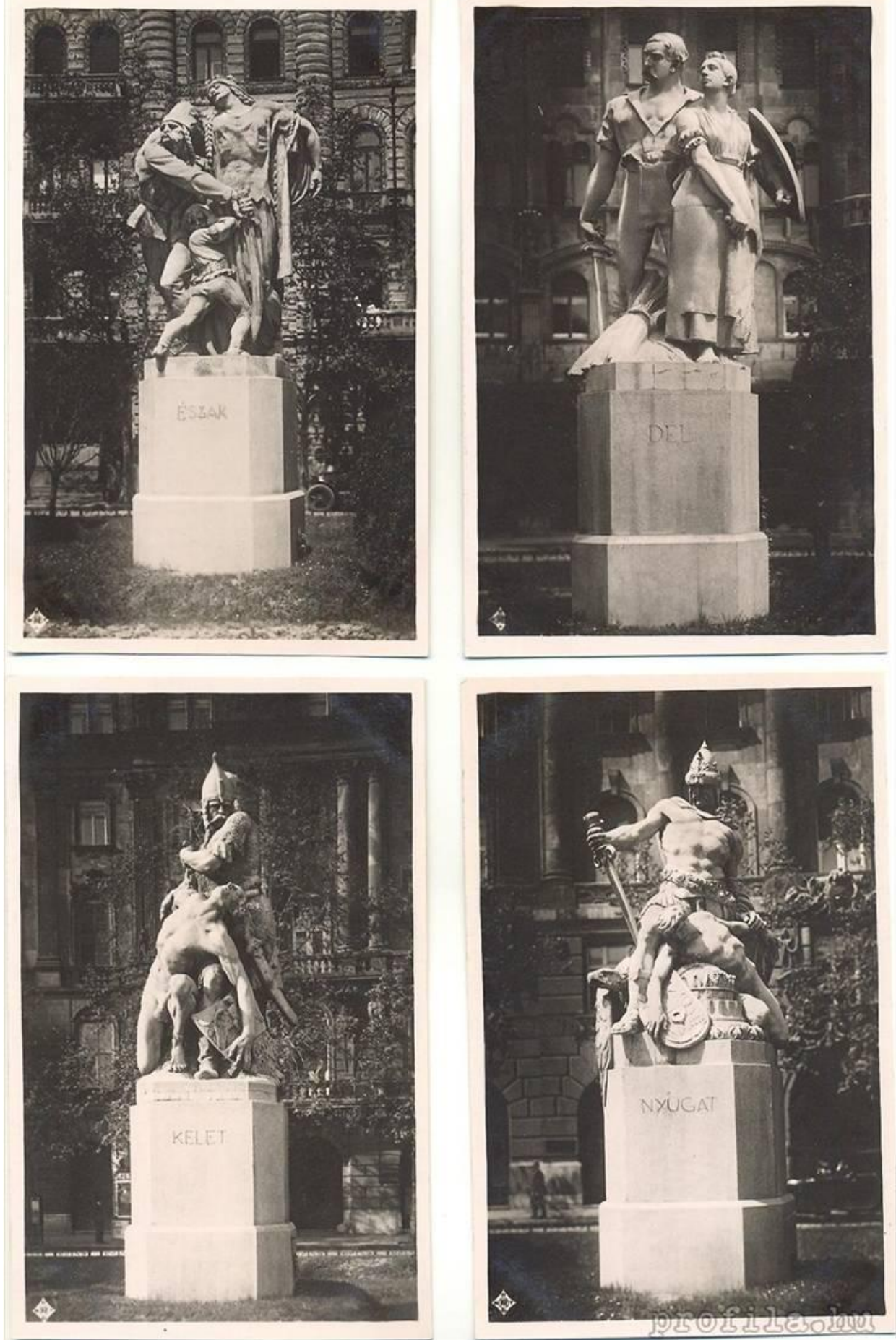

Fig. 5 The 1921 statues on Szabadsag tér.

\section{Source: http://www.profila.hu/site_media/upload/127/L_-34366127.jpg}

The statues were called "North", "East", "South", and "West" and were placed in a semi-circle in the direction of the Parliament Building. As Miklós Zeidler writes:

The figure tumbling on the holy crown in the statue entitled West was holding the coats of arms of the lost counties in his right and a shield with the double cross in his left hand. A turul bird was resting at his feet. On the three-figure composition of North a Slovak boy seeking protection was leaning on a crucified Hungaria and a well-built Kuruc soldier was protecting both with his sword. 
Erik Thorstensen. "The Places of Memory in a Square of Monuments: Conceptions of Past, Freedom and History at Szabadság Tér. AHEA: E-journal of the American Hungarian Educators Association, Volume 5 (2012): http://ahea.net/e-journal/volume-52012

The allegory of East depicted chieftain Csaba in a heroic pose as he was liberating the symbolic figure holding Transylvania's coat of arms. On the statue entitled South there was a strong-muscled Hungarian man embracing and protecting a Swabian girl, who symbolised the southern region (Zeidler 2002: 73)

Such obvious romantic imagery of mythic birds, a crucified country, ancient fighters, and a man who protects a maid do not point towards a specific period, but towards a "spirit" or a condition; a condition by and large called l'Ancien Régime or feudal society in which a natural order of things and men under God is said to have existed. The onlooker is reminded that the Treaty of Trianon is why such chaos existed in Hungary. These four monuments are called irredentist since they evoke the suppression of the Treaty as the only righteous and just solution. ${ }^{2}$

In 1926 the first monument to commemorate the revolution in 1848/49 was erected on the periphery of Szabadság tér. It was built in memory of the martyrs executed on 6 October 1849. On that day Lajos Batthyány, the first Prime Minister of Hungary, was executed in the Újépület and thirteen Hungarian generals supporting the rebellion against Austria executed in Arad in present-day Romania. This eternal flame, designed by Móric Pogány, is located on the spot where Batthyány is supposed to have been executed in 1849 (Gerö 2006, 130, 304).

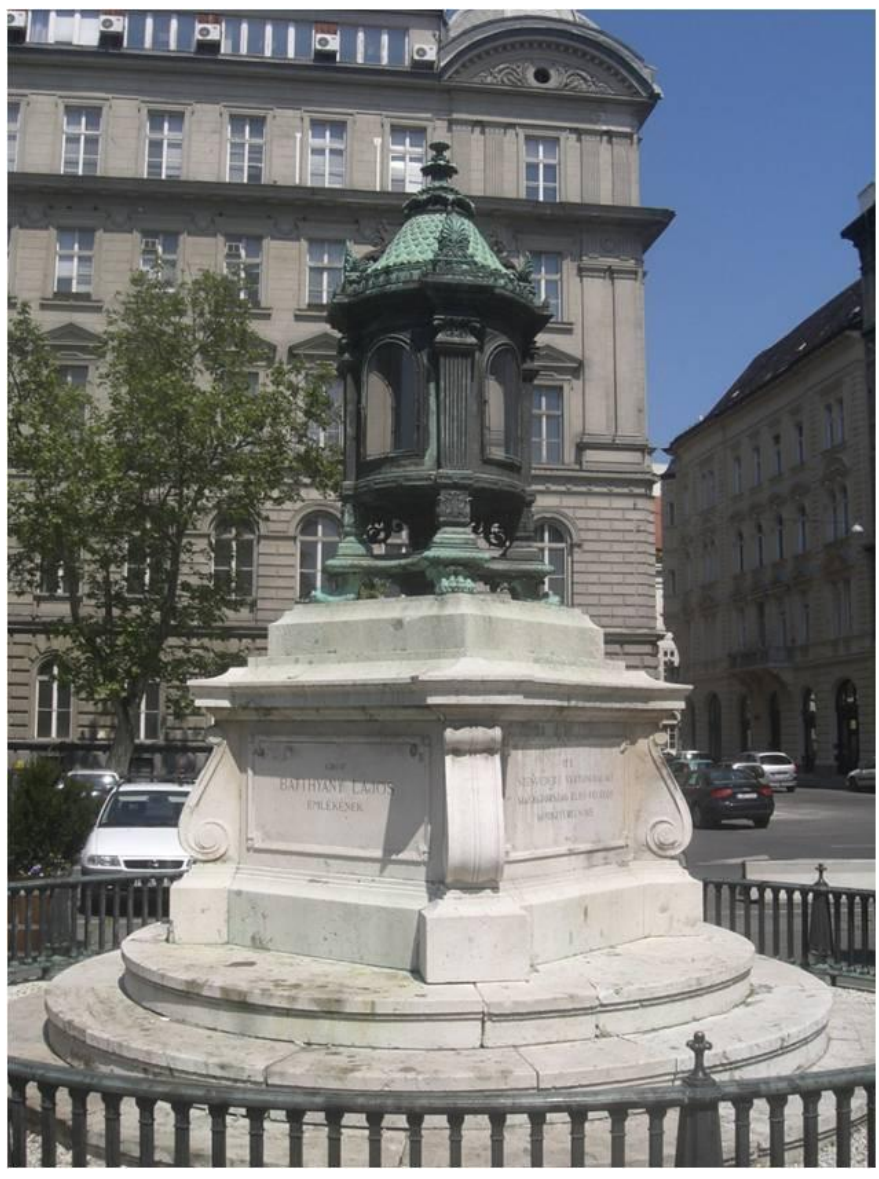

Fig. 6 Eternal lantern. Source: Photo by author. ㅇ Erik Thorstensen.

\footnotetext{
${ }^{2}$ The term "irredentist" refers to aspirations "to take back national territories under foreign rule either peacefully or by force" while "revisionism can be defined as the attempt to modify the terms of a treaty through diplomacy and international law" (Caples $2005,57)$. Since monuments rarely thematize methods, but are only about goals that have been achieved and should be reachieved the term "irredentist" seems proper to describe these monuments.
} 
Erik Thorstensen. "The Places of Memory in a Square of Monuments: Conceptions of Past, Freedom and History at Szabadság Tér. AHEA: E-journal of the American Hungarian Educators Association, Volume 5 (2012): http://ahea.net/e-journal/volume-52012

Shaped as a lantern, the symbolism connotes light vs. darkness where the martyrs' deeds keep the darkness away. Manichean symbolism of this kind confers a history of victimization, and constructs an ethical outcome of history, where the good are rewarded and the evil are punished (Ahonen 2011). This monument is the only one that refers to Szabadság tér itself and its past since it is located on the place where Batthyány was executed. The inclusion of the "Arad martyrs" - Arad being located in Romania after 1920 can be interpreted as a way of including the plight of Hungarians outside of Hungary in a Hungarian national canon.

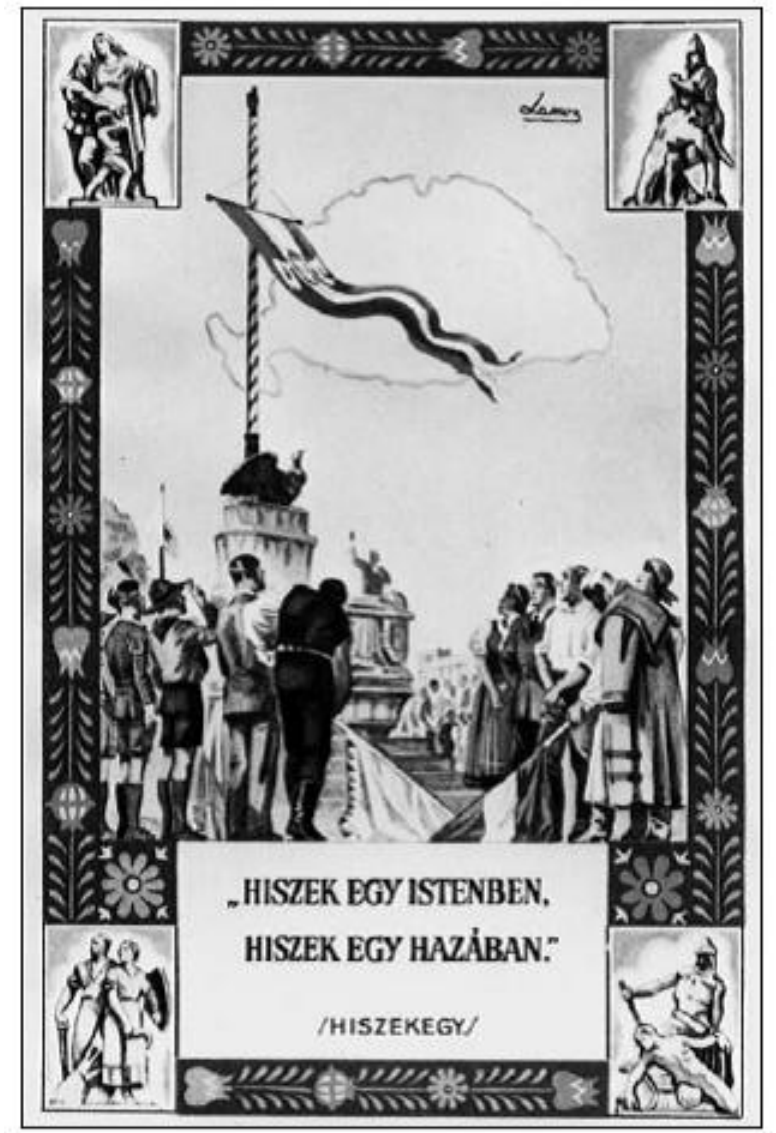

Fig. 7 Picture card of the national flag. Source: Zeidler "Irredentism" 74.

The demi-circle of irredentist statues received its center in 1928. On St. Stephen's Day, 20 August 1928, a twenty meter flagpole with a one meter-long hand on the top (cast after Horthy's own hand) was presented with the Hungarian flag on half mast as a sign of grieving the loss of land (Zeidler 2002, 73). The flag rested on a pedestal with earth from each of the counties within the borders of pre-Trianon Hungary (Caples 2005, 57). According to an American travel reportage, the flag was to remain at half mast until Hungary was restored to its pre-Trianon borders (Dengizik1 2011). Such a dramatization of Hungary's death can be understood as a dramatic acceleration in imagery and rhetoric. Whereas the condition referred to by the original four statues was the loss of paradise, the addition of the flag pole in 1928 symbolized the country's death. The Christian narrative underlying such symbolism would have been obvious to most Christian Hungarians. This narrative rests upon an understanding that, though death is a qualitatively different condition from life, it is also necessary according to Christian doctrine for salvation, and salvation depends on correct fidelity and/or proper activity. The monument is (literally) pointing towards the sky where the future is open, but in order for Hungary to rise, the onlookers must perform the correct actions that can reestablish the terrestrial paradise. The monument is very open to interpretation when it comes to the means for achieving this state, but the goal is the resurrection of a now lost nationalist past. 
Erik Thorstensen. "The Places of Memory in a Square of Monuments: Conceptions of Past, Freedom and History at Szabadság Tér. AHEA: E-journal of the American Hungarian Educators Association, Volume 5 (2012): http://ahea.net/e-journal/volume-52012

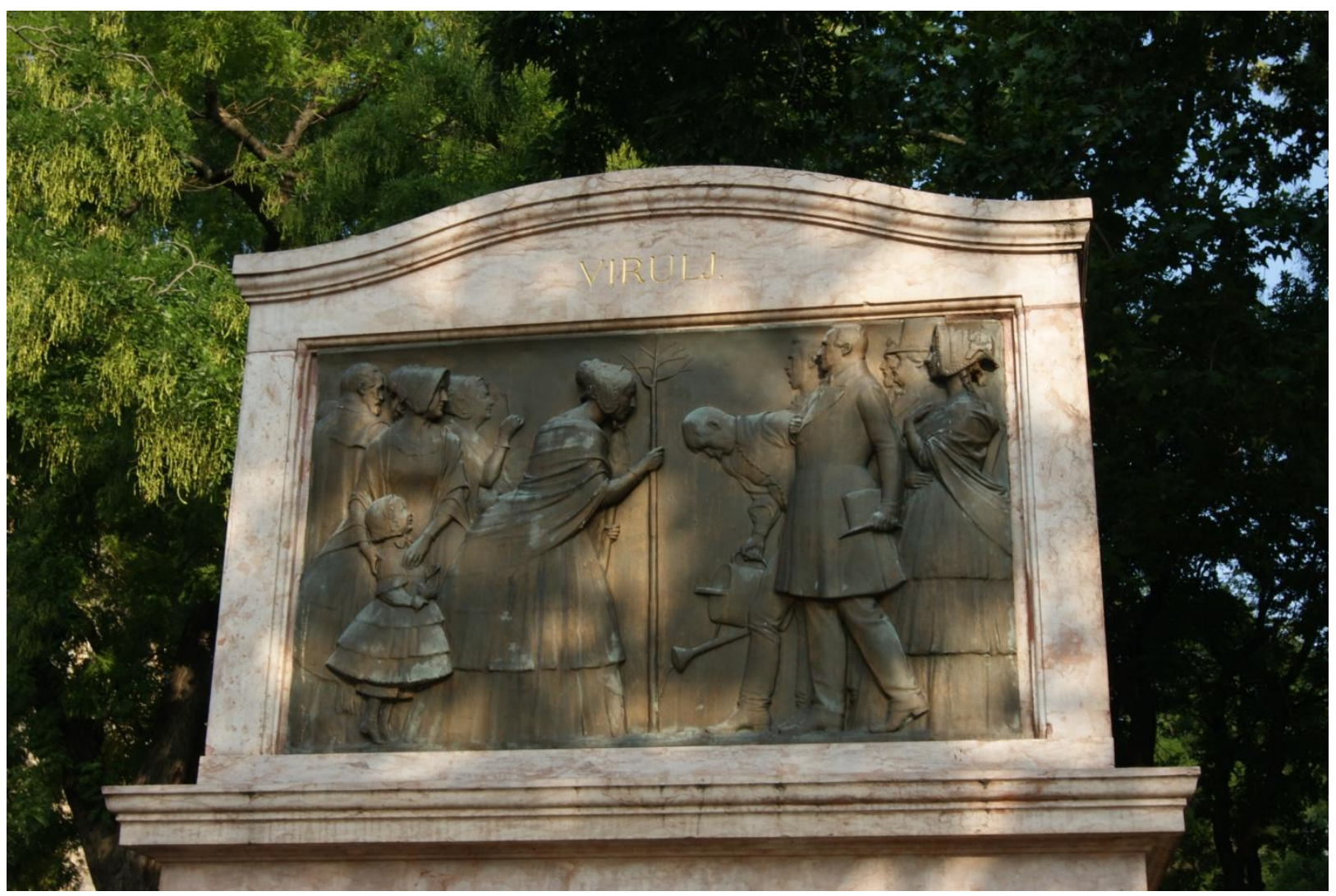

Fig. 8 Memorial over István Széchenyi, "Flourish". Photo by Cecilie Endresen. (c) Cecilie Endresen.

Not all monuments are easily accessible, as the 1930 memorial celebrating István Széchenyi can attest. Named "Flourish", the Széchenyi memorial is discrete in its pinkish marble with a bronze relief. ${ }^{3}$ Széchenyi's part in Hungarian national lore is mainly connected to the cultural field. He was the first person to speak Hungarian in the Upper Chamber in the Hungarian Diet in 1825 and, amongst many other achievements, was the founder of the Hungarian Academy of Sciences (Lendvai 2003, 195). Széchenyi was a leading figure in the 1848/49 uprising, but on the side that wanted to remain within the Habsburg Empire. The relief depicts Széchenyi and his wife, Countess Crescence Seilern, planting trees in Budapest in 1846. The period of the past that is to be remembered here is the years between 1825 and 1846 . The monument can be interpreted as a story about the necessity to plant seeds for a change to occur. It can be seen as recognition of Széchenyi's effort for the Hungarian national cause, but also a reminder to the onlooker to step aside after the seeds have been planted and await those who shall harvest. The monument can then be understood as a call for national action in the 1930s, but without challenging the "natural order of things"; that is not to revolt, but remain committed to the present ruling regime and await the liberation to come just as Széchenyi had pleaded for a gradual change. The Horthy regime did not want to regard Trianon as the result of misguided politics, but created a narrative where the Treaty of Trianon was understood as the causes of Hungary's misfortune, and in turn depicted the Habsburg era as a politically and nationally desirable regime, one whose main fault had been to allow its subjects too much political liberty (Gerő 2006, 199). Thus, Széchenyi's combined loyalty to the Habsburg monarchy and his struggle for Hungarian national expressions were values that resonated with the Horthy regime, while the celebration of Széchenyi's life also constituted a celebration of the Horthy regime itself.

\footnotetext{
${ }^{3}$ All of the information concerning the monuments' age and titles is found in Budapest Galeria (n.d.) unless other references are given.
} 

Tér. AHEA: E-journal of the American Hungarian Educators Association, Volume 5 (2012): http://ahea.net/e-journal/volume-52012

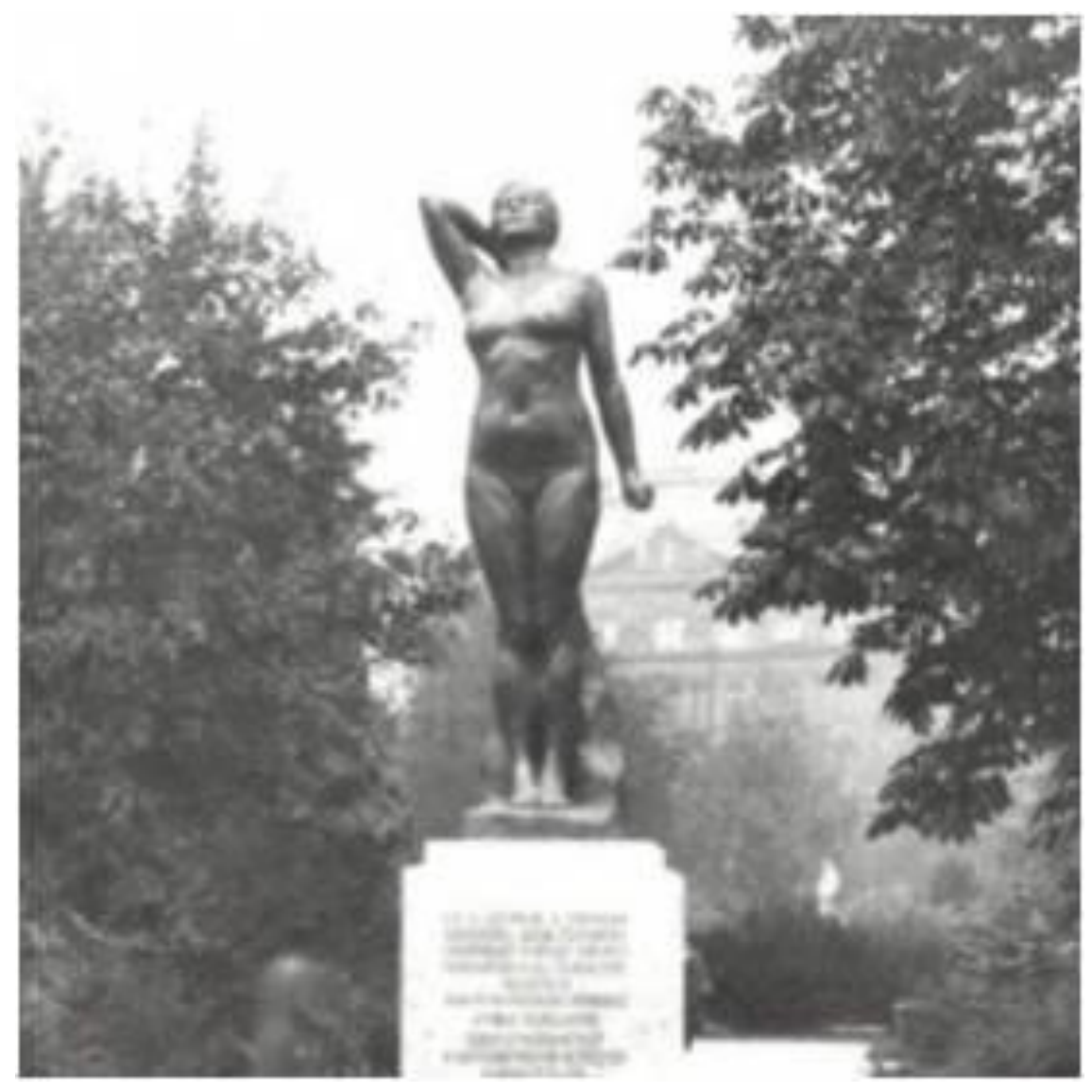

Fig. 9 Statue of Hungarian Grief. Source:

http://www.szoborlap.hu/13981_magyar_fajdalom_szobra_budapest_emile_guillaume_1932.html?f=photo

The dichotomy between life and death is further strengthened by the "Statue of Hungarian Grief" by the French sculptor Émile Guillaume. It was unveiled by the British anti-Trianon advocate Lord Rothemere on 6 October 1932, the day the martyrs were executed in 1849. The statue shows a nude woman with desperate gestures mourning the loss of her children. The woman is meant to be, as the pedestal explains, post-Trianon Hungary (Szoborlap, n.d.). ${ }^{4}$

\footnotetext{
${ }^{4}$. See also the unveiling online (Filmhíradók online (a))
} 
Erik Thorstensen. "The Places of Memory in a Square of Monuments: Conceptions of Past, Freedom and History at Szabadság Tér. AHEA: E-journal of the American Hungarian Educators Association, Volume 5 (2012): http://ahea.net/e-journal/volume-52012

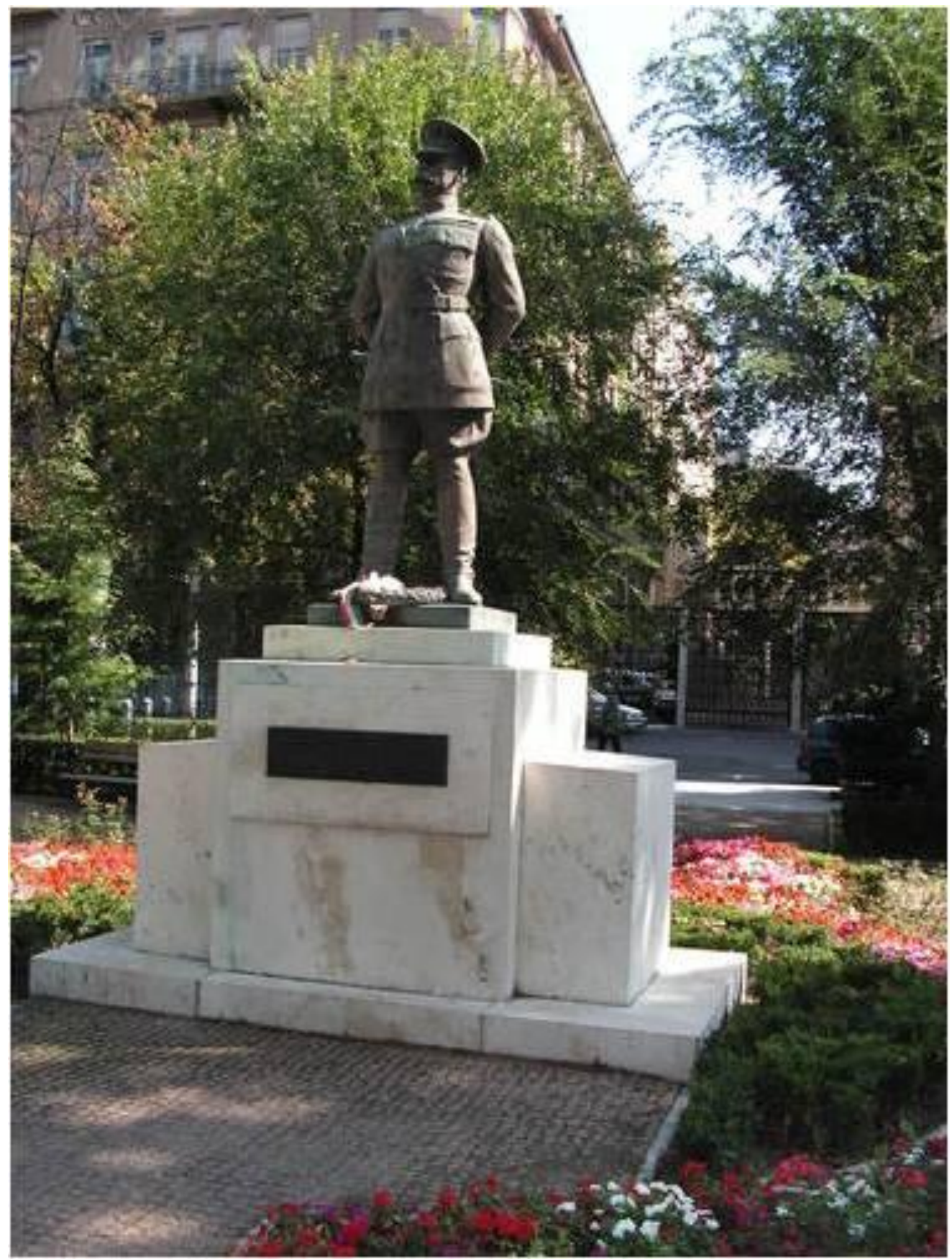

Fig. 10 Harry Hill Bandholtz. Source: Photo by author. (C) Erik Thorstensen.

The next statue to be erected was that of the American colonel Harry Hill Bandholtz in 1936. Bandholtz was remembered for preventing the Romanian army from looting the cultural museums in Budapest, and thus helped secure Hungary's access to its material past. This imagery creates a story where Hungarians are not alone in their fight, and at the same time depend upon foreign help. It is difficult not to place Hungary's memorials of the 1920s-40s in relation to the increasing cooperation with Fascist Italy and Nazi Germany. In 1936 Hungary, on the initiative from Prime Minister Gömbös, entered into an alliance with the Axis powers, one which was formalized under Teleki in 1940. The official and unofficial involvement with fascism lasted from the early 1920s (Lendvai 2003, 387-413), and in the 1930s squares in Budapest were named after both Hitler and Mussolini (Ziedler 2002, 75). 
Erik Thorstensen. "The Places of Memory in a Square of Monuments: Conceptions of Past, Freedom and History at Szabadság Tér. AHEA: E-journal of the American Hungarian Educators Association, Volume 5 (2012): http://ahea.net/e-journal/volume-52012

In November 1938, the flag was raised on the twenty meter pole on Szabadság tér to full mast to celebrate the first Vienna Award, a treaty where Nazi Germany (and Italy) secured parts of Czechoslovakia for the Kingdom of Hungary. These territories had been part of pre-Trianon Hungary (Lendvai 2003, 409). In the following years Admiral Horthy fulfilled his promise of re-uniting the lost provinces by annexing former northern Hungary and Ruthenia from Czechoslovakia in 1938 and 1939, and a part of Transylvania from Romania in 1940, and by conquering (together with Germany) its former southern territories in Yugoslavia in 1942 (Gerö 2006, 207).

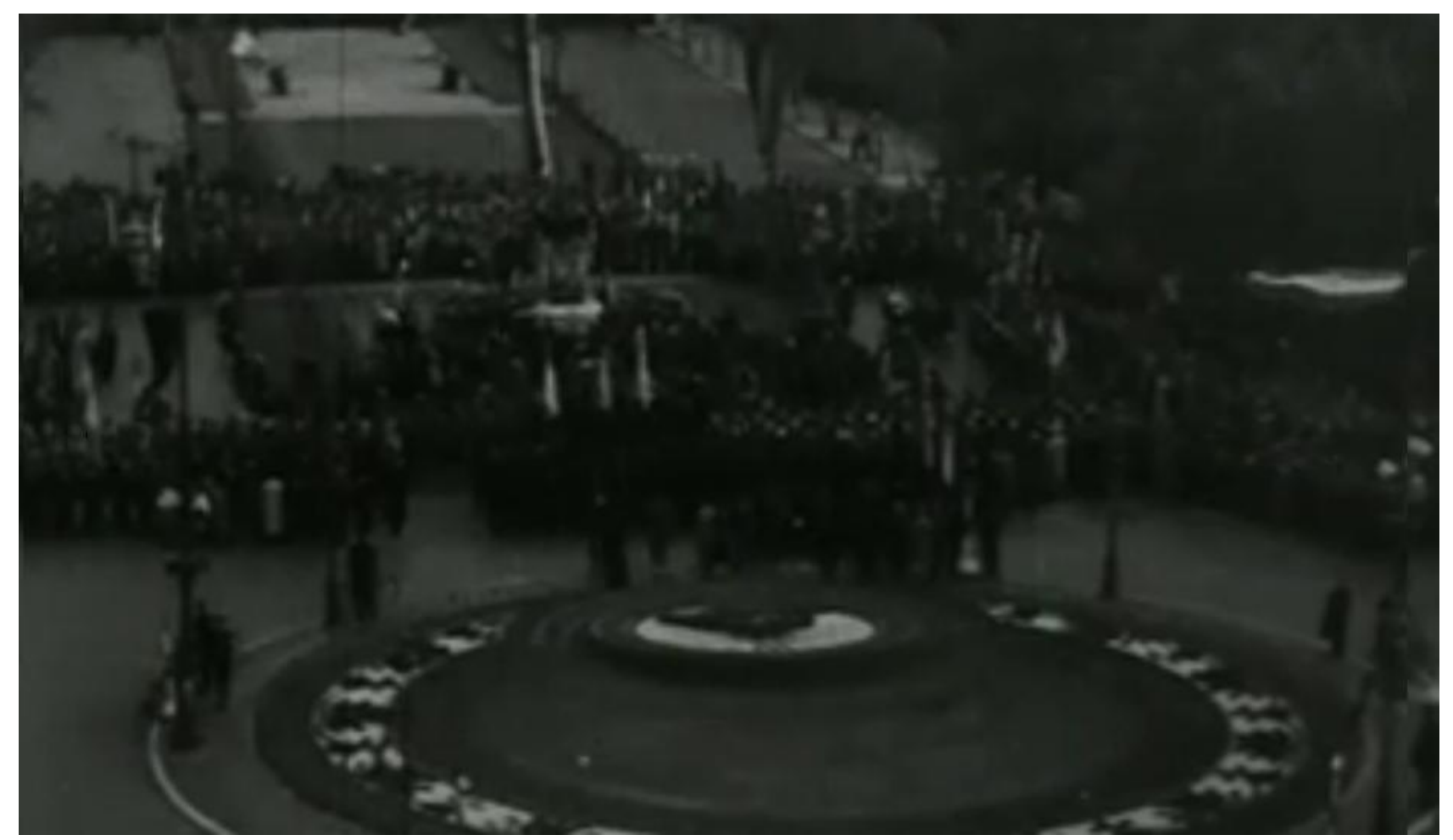

Fig. 11 The Flag on full mast in 1938. Source: Filmhíradók online (b).

With the flag at full mast in 1938 the past it refers to and the meaning of that past changed since it now became a monument of victory, and consequently a monument celebrating Nazi Germany's occupation of Czechoslovakia (and later other countries). There is potentially much aggression present in a monument celebrating the defeat of Hungary's neighbor since it signals that this deed is to be re-lived and commemorated by future generations of Hungarians. 
Erik Thorstensen. "The Places of Memory in a Square of Monuments: Conceptions of Past, Freedom and History at Szabadság Tér. AHEA: E-journal of the American Hungarian Educators Association, Volume 5 (2012): http://ahea.net/e-journal/volume-52012

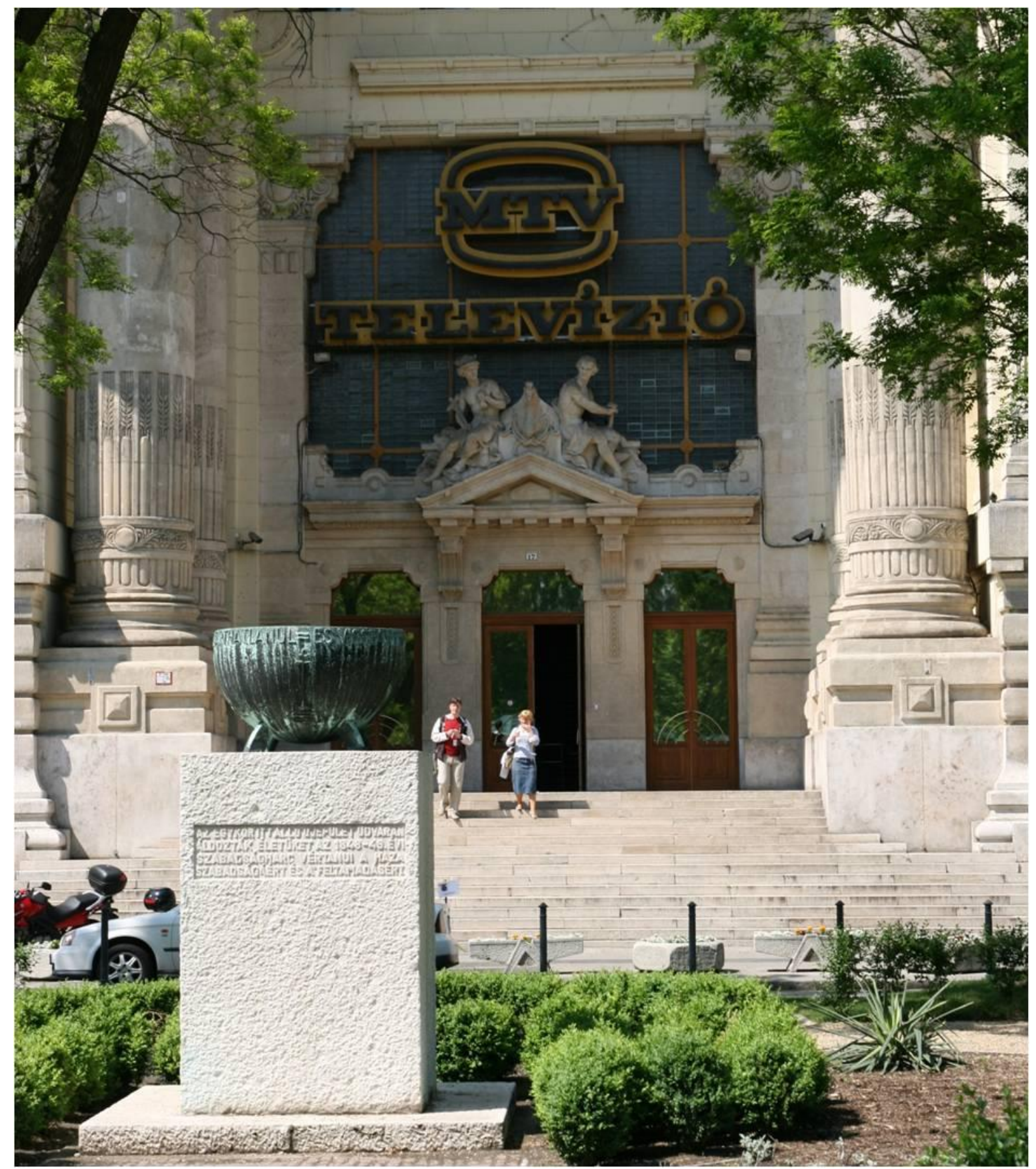

\section{Fig. 12 For the martyrs in the Újépület. Source: Photo by author. (C) Erik Thorstensen.}

The bronze bowl to remember all the martyrs who lost their lives in Újépület during 1848/49 was installed in 1940 in front of what between 1955 and 2009 was the headquarters for the Hungarian Television. This bowl connotes a chalice (or the grail) used for the Eucharist and thereby compares the martyrs to Jesus since the wine served during the Last Supper was referred to by Jesus, according to Christian myths, as "his blood". Even though Hungary did not enter World War II militarily before the April 1941 invasion of Yugoslavia, the calls for martyrdom, both symbolic and real, alluded to the Manichean ideal of "conquer or die", especially in an actual situation of armed conflict. Seen in relation to the raised flag from 1938, this story and celebration of proto-martyrs can serve as a reminder to the people that there is a new war of liberation in Europe - and the Hungarians must once again be prepared to make sacrifices. 
Erik Thorstensen. "The Places of Memory in a Square of Monuments: Conceptions of Past, Freedom and History at Szabadság Tér. AHEA: E-journal of the American Hungarian Educators Association, Volume 5 (2012): http://ahea.net/e-journal/volume-52012

Seen in their totality, the Horthy-era monuments in Szabadság tér tell a story of continuity where the proto-revolutionary heroes up to 1849 played a significant part. The Horthy era has only one monument celebrating its own success, the raised flag. It is further significant that the irredentist monuments were left standing even after the re-conquering of almost the whole pre-Trianon territory by 1944 . There are several theoretical possibilities as to why they were not demolished, and I will mention two that can facilitate the reading of the present Szabadság tér. The first reason why they were left is connected to the meaning of the monuments. The remaining irredentist monuments point towards an imagined pristine spirit or condition of pre-Trianon Hungary and thus constitute a part of the Hungarian canon. The second reason is connected to the archival aspect of the monuments. A removal of the irredentist monuments would have eliminated material signs of the Horthy regime's struggle to unite its people. Such material remains serve to make the alleged necessity of a united Hungary even more real since they their archival aspect referred to a period where this unity was lost.

Seen in their totality, the Horthy-era monuments in Szabadság tér tell a story of continuity where the proto-revolutionary heroes up to 1849 played a significant part. The Horthy era has only one monument celebrating its own success, the raised flag. It is further significant that the irredentist monuments were left standing even after the re-conquering of almost the whole pre-Trianon territory by 1944 . There are several theoretical possibilities as to why they were not demolished, and I will mention two that can facilitate the reading of the present Szabadság tér. The first reason why they were left is connected to the meaning of the monuments. The remaining irredentist monuments point towards an imagined pristine spirit or condition of pre-Trianon Hungary and thus constitute a part of the Hungarian canon. The second reason is connected to the archival aspect of the monuments. A removal of the irredentist monuments would have eliminated material signs of the Horthy regime's struggle to unite its people. Such material remains serve to make the alleged necessity of a united Hungary even more real since they their archival aspect referred to a period where this unity was lost.

\section{Szabadság tér under Communist rule}

Under Communist rule, explicit references to Greater Hungary were removed, but many material traces of the Horthy era remained. The Soviet Red Army demolished the whole of the irredentist monuments in 1945 (namely the four statues and the flag pole). In addition they removed the statue of Harry Hill Bandholtz to a storage facility and the "Statue of Hungarian Grief" to Margaret Island (Zsolt 2006, 5). In their place the Red Army erected the large obelisk, and called it a monument to the "Soviet Union's liberation of Budapest" with the Communist star on top that is still present at the Square that was inaugurated on the 1 May 1945 (Zsolt 2006, 3).

In order to understand why one monument complex was destroyed, two monuments were removed, and a series of monuments referring to the national revolution in 1848/49 were kept in place, we need to look at the canonical side of the monuments. The selective removal in the Communist period is characterized by dislocations or destructions of monuments referring to an irredentist future and by the keeping of monuments referring to the - in Communist eyes - anti-imperialist struggle against Austria. The remaining monuments served to inscribe the Hungarian Communist regime into Hungarian national history. As Tony Judt claims, Soviet ideology understood itself in relation to the European revolutions of 1848/49: "The Communists' stated objective in 1945 and 1946 was to 'complete' the unfinished bourgeois revolutions of 1848, to re-distribute property, guarantee equality and affirm democratic rights in a part of Europe where all three had been in short supply." (Judt 131)

Judt's insight can be used as a key to understand why the monuments that celebrate martyrdom and revolt were kept intact during the Communist period. The story told by the monuments was part of a history that Communism regarded as its own, and the Communist "canonization" of the past superseded the material presence of the Horthy years. Such an embracing of the national revolutions is also seen at Hösök tere with the above-mentioned installment of secular national heroes instead of Habsburg monarchs. The Soviet liberation monument replaced the monument Horthy erected to celebrate what he perceived to be the liberation of pre-Trianon Hungary. This replacement can be seen as the crushing of Horthy's conception of 
Erik Thorstensen. "The Places of Memory in a Square of Monuments: Conceptions of Past, Freedom and History at Szabadság Tér. AHEA: E-journal of the American Hungarian Educators Association, Volume 5 (2012): http://ahea.net/e-journal/volume-52012

freedom both ideologically by the Soviet Communism and concretely by erecting a new monument, an obelisk which connotes past grandeur as well as imperial power in the tradition we know both from Rome, Paris, and London.

With help from Judt's line of thinking we can also understand why the martyr monuments were kept in place, as well as the monument of Széchenyi. The removal of the irredentist monuments changes the possible interpretations of the Széchenyi monument since his deeds are no longer connected to the abolishment of Trianon, but rather points towards the Communist regime. All these represent the popular struggle against the Habsburg monarchy and are therefore monuments for the revolution, in Communist logic.

In contrast to the removal of the irredentist statues I believe that the removal of the Bandholtz monument was primarily due to his American nationality. Less important in this process was the fact that he chased away Romanians, a people from a country that at the time was located in the Soviet sphere of interest after the meeting in Teheran between Churchill, Stalin and Roosevelt in 1944 (Judt 2005, 101). My hypothesis is that the Bandholtz statue might have been kept had he been from a country without stakes in the liberation of Europe. The Americans must also have been content that the statue was removed since its existence outside of the American Embassy in Budapest would have been a constant reminder of the adoption by the Horthy regime of an American officer.

From what I have been able to document, no further monuments were built on Szabadság tér in the Communist era - even though many other monuments were built in in Budapest in that period. Göran Therborn (2006, 222) writes that "Budapest counted 19 monuments in 1900, 37 by the end of the Habsburgs in 1918, 140 by the fall of the rightwing regime in 1945, and 350 in 2000, most of whose net number must have risen before 1989". However, at Szabadság tér only one new monument was installed, but one which in Communist historical understanding, marked the final victory of the revolutions from 1848/49.

\section{Szabadság tér in post-communist Hungary}

As early as 1990, “[t]he Holy Crown Association (Szent Korona Szövetség) suggested returning the Trianon memorial commemorating pre-WWI Hungary to Szabadság tér to replace the Soviet Liberation memorial." (Palonen 2008, 224). In the ensuing debates in Parliament on the issue - both in 1990 and in 2001 - no final conclusion was drawn, which meant that the status quo remained (Palonen 2002, 3-4).

But before the debates about returning the interwar memorial took place, two monuments were installed on Szabadság tér in 1989: the statue of Harry Hill Bandholtz was reinstalled and a plaque commemorating Cardinal József Mindszenty (1892-1975) was put in place without any perceivable public discussion. 
Erik Thorstensen. "The Places of Memory in a Square of Monuments: Conceptions of Past, Freedom and History at Szabadság Tér. AHEA: E-journal of the American Hungarian Educators Association, Volume 5 (2012): http://ahea.net/e-journal/volume-52012

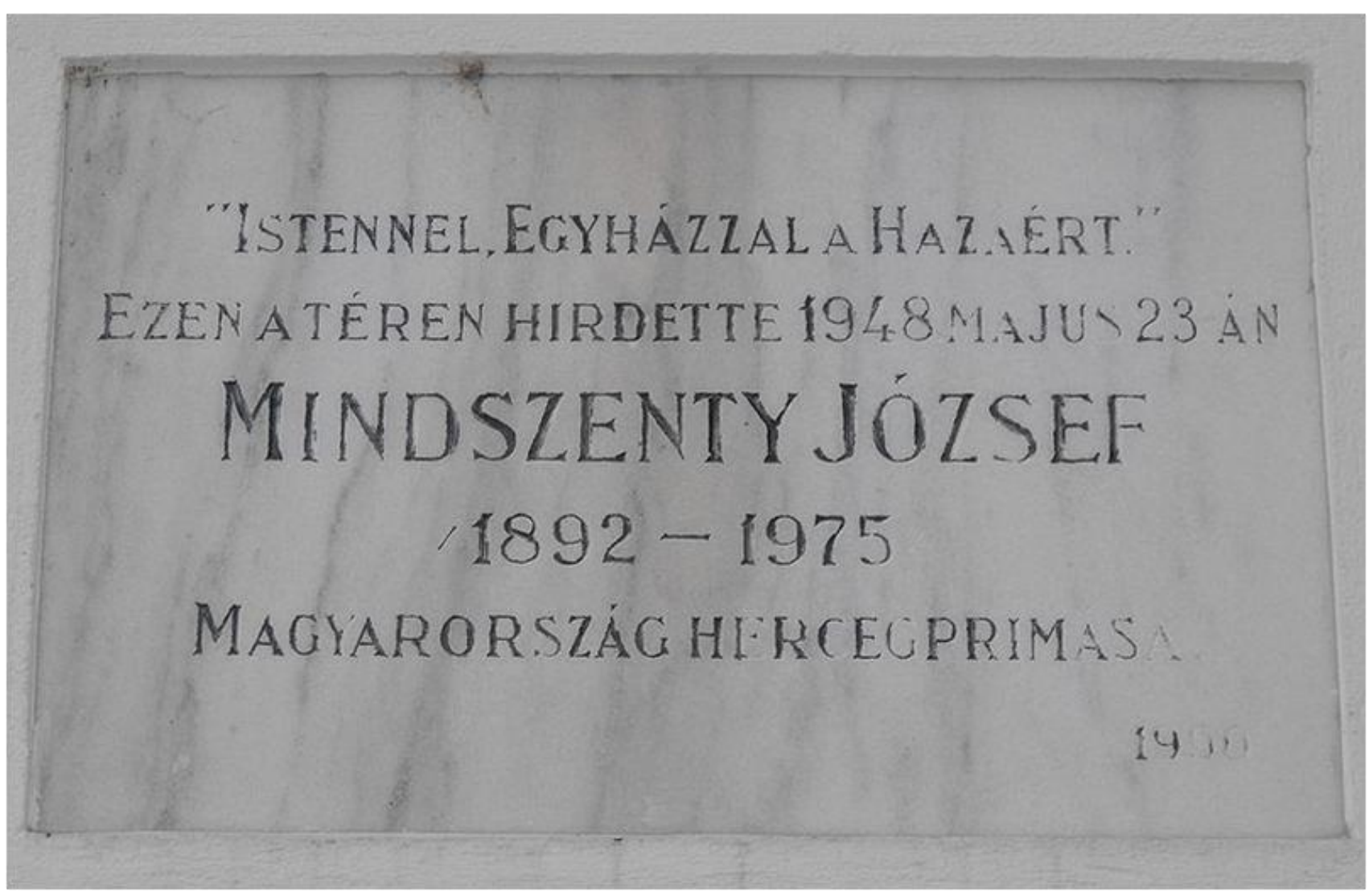

Fig. 13 Memorial plaque over Cardinal József Mindszenty. Source: Photo by author. (C) Erik Thorstensen.

Cardinal Mindszenty was one of the most outspoken critics of Communism in Hungary, and was in a combination of exile and house arrest at the American Embassy in Budapest from 1956 to 1971 when he was allowed to leave for the Vatican where he joined the Pope's curia (Adriányi 1993). The monument to him can then be understood as a commemoration of civic revolt and religious victory combined. From a nationalistic perspective the 1956 revolt mirrors the 1848/49 revolution, and like the monuments commemorating the 1848/49 revolution the plaque dedicated to Mindszenty also connotes that freedom will come to those who believe in it and fight for it. The installation of the Mindszenty plaque certainly indicates that the Catholic faith is seen as central to both Hungarian nationalism and the freedom that was gained in 1989. It is noteworthy, however, that the plaque refers to a cardinal that did not win any concrete victories over the Communists. Nevertheless, his defeat resonates well with the 1848/49 monuments since these also mark losses, but losses that were necessary for the future of a great nation. According to such logic the personal sacrifices he made are praised as a prerequisite for national salvation and are structurally similar to the irredentist thinking of the interwar period. The obvious difference between the Mindszenty plaque and the irredentist monuments, however, is that the latter did not refer to or point to a specific person but rather to the Hungarian people as an imagined community.

While I posited that the main reason that the Soviets took down the Bandholtz' statue was because of the general's American nationality, I suspect that, ironically, it was also reinstalled for the same reason. His statue could be made part of the freedom story told at Szabadság tér because Bandholtz' intervention was not part of Horthy politics, neither was he part of the Bela Kun regime but lived during a period that which can be celebrated today since it is neither under Austrian rule nor Fascist or Communist rule. A few months during 1919 constitute the only period that could be made part of a Hungarian canon. The three months between Kun's flight on 4 August 4 1919, and Horthy's white horse entrance on 16 November 1919 constitute a period that could be made part of a Hungarian canon according to Assmann's theoretical framework. 
Erik Thorstensen. "The Places of Memory in a Square of Monuments: Conceptions of Past, Freedom and History at Szabadság Tér. AHEA: E-journal of the American Hungarian Educators Association, Volume 5 (2012): http://ahea.net/e-journal/volume-52012

During the 1990s and the early years of 2000, several new installments were made on Szabadság tér which created the square that I encountered in the spring 2008.

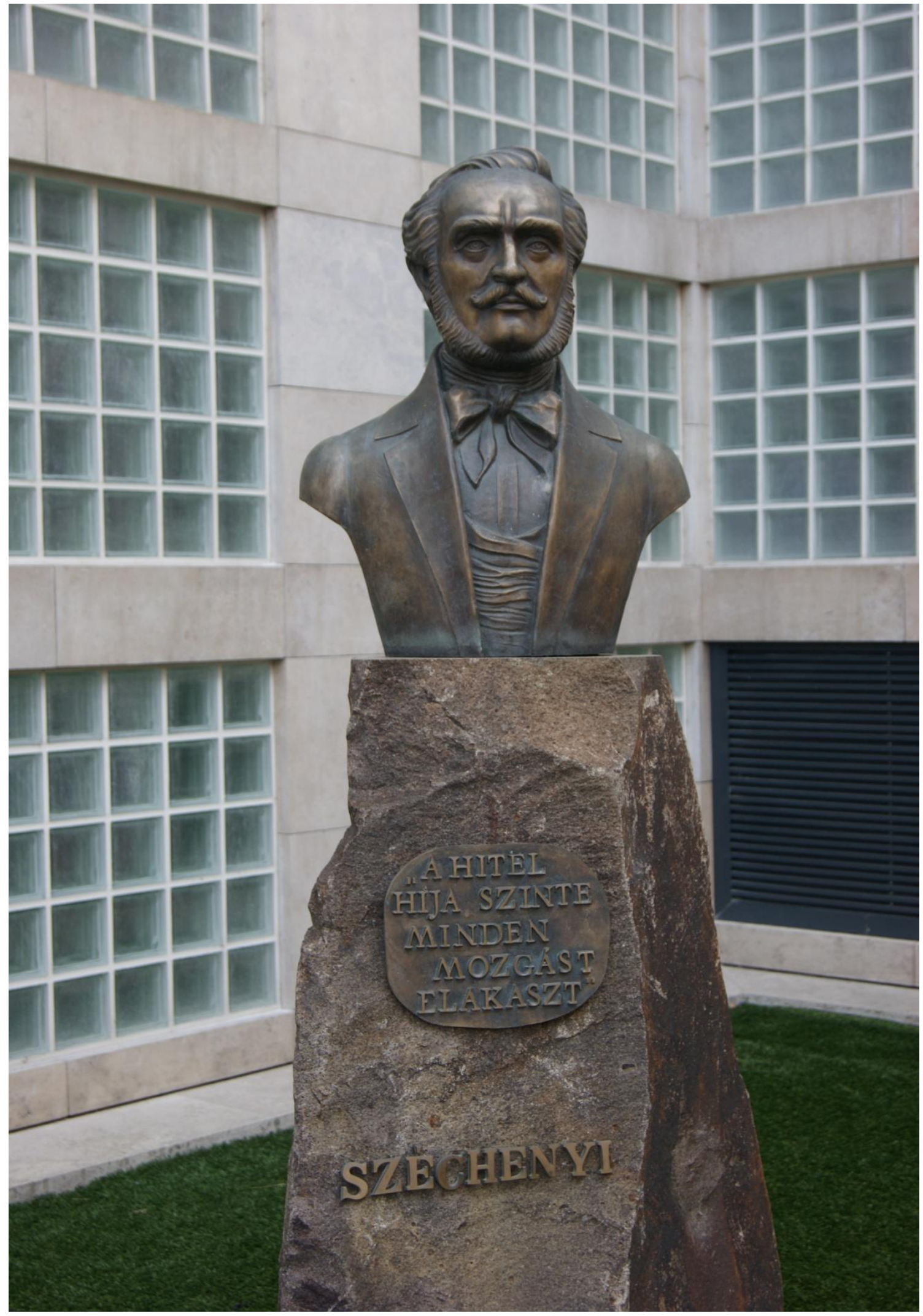

Fig. 14 Bust of István Széchenyi. Source: Photo by Cecilie Endresen. (C) Cecilie Endresen. 
Erik Thorstensen. "The Places of Memory in a Square of Monuments: Conceptions of Past, Freedom and History at Szabadság Tér. AHEA: E-journal of the American Hungarian Educators Association, Volume 5 (2012): http://ahea.net/e-journal/volume-52012

The bust of István Széchenyi was the first to appear in 1991, even though he already was present on the Szabadság tér. This time he was represented by a bronze statue, and it was sponsored by the Hungarian Credit Bank (MHB - Magyar Hitel Bank). ${ }^{5}$ This statue refers to the sphere where economic and political freedoms intersect. Széchenyi's book Hitel (Credit) from 1830 argued that normal credit relations were necessary in order to modernize agriculture in Hungary (Lendvai 2003, 198). On the pedestal of Széchenyi's statue there is the following quote: "A hitel híja szinte minden mozgást elakaszt", which translates as "The lack of credit prevents nearly everything to move". Again it is the enlightenment aspect of Széchenyi's project which is emphasized and not his political project that is made part of a story that also includes the rebels from 1848/49.

This economic turn is likewise the only logical explanation of the non-figurative work of art called "Composition/The Force of traces" by Adám Farkas in 1996 with the Bank Center as its sponsor.

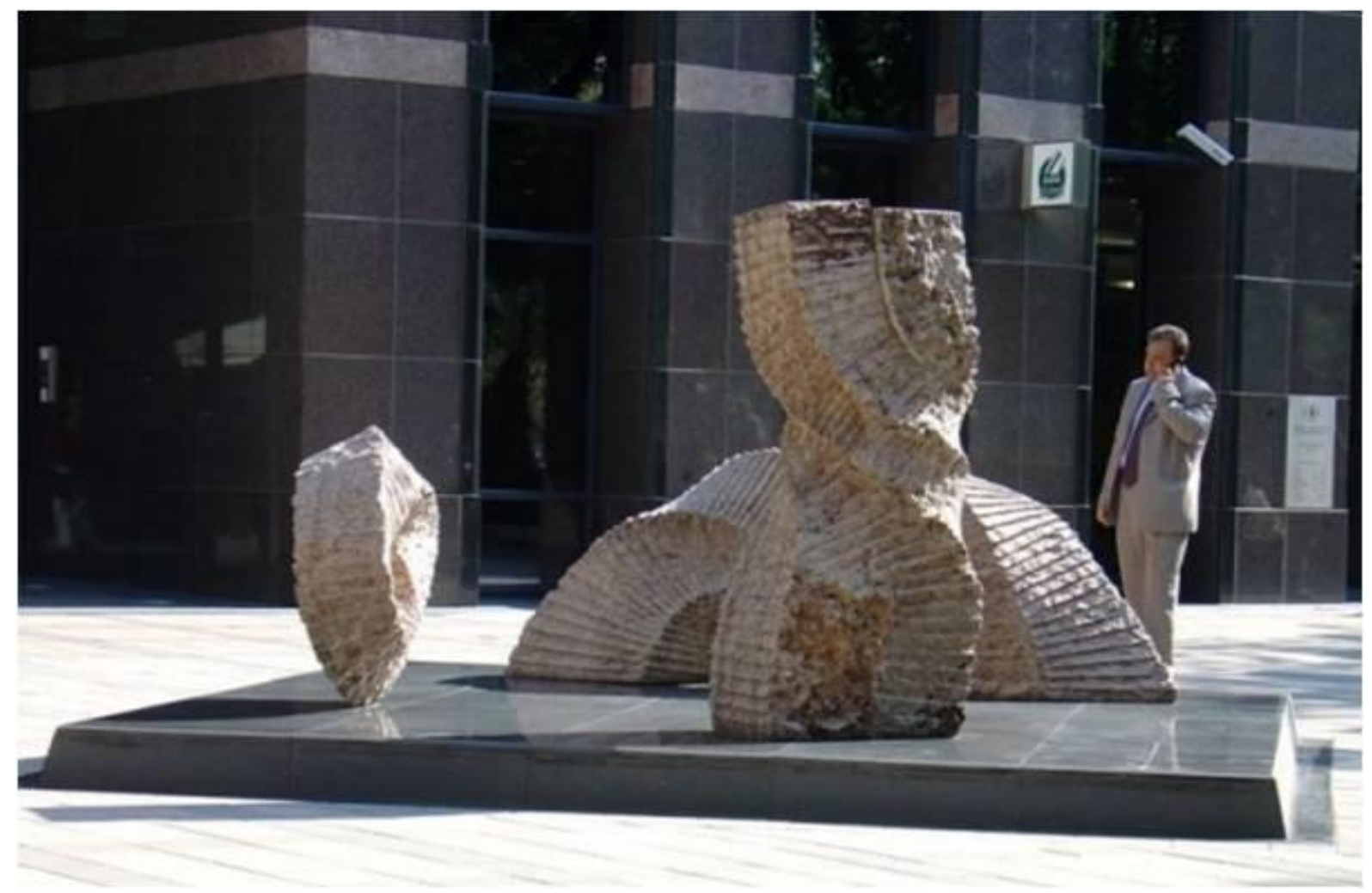

Fig. 15 Composition/The Force of traces. Source: Photo by author. (C) Erik Thorstensen.

Given its abstract character and the fact that it does not refer to a past event, it cannot classify as a monument, but given its location and the surroundings, I think it would be wrong to exclude it from the Square's totality. It can only be understood as a celebration of the time that made it possible to install it at the Square.

\footnotetext{
${ }^{5}$ Magyar Hitel Bank was founded in 1986 and one of the leading banks in the privatization of Hungarian economy until its sale in 1996 to Dutch ABN (Neale and Boszik 2001, 15).
} 
Erik Thorstensen. "The Places of Memory in a Square of Monuments: Conceptions of Past, Freedom and History at Szabadság Tér. AHEA: E-journal of the American Hungarian Educators Association, Volume 5 (2012): http://ahea.net/e-journal/volume-52012

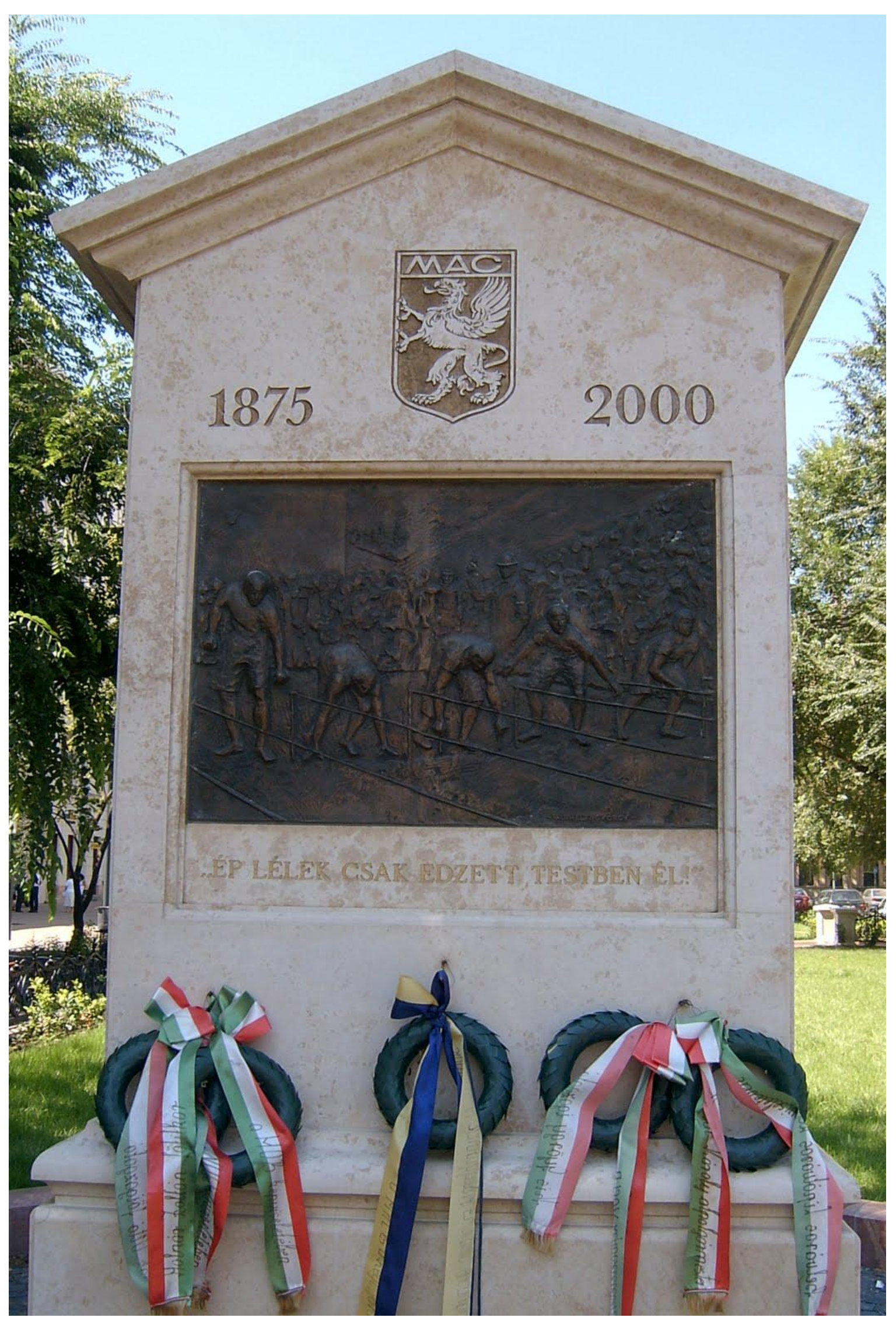

Fig. 16 Magyar Atlétikai Club. Source: György Pretz. @ György Pretz. 
Erik Thorstensen. "The Places of Memory in a Square of Monuments: Conceptions of Past, Freedom and History at Szabadság Tér. AHEA: E-journal of the American Hungarian Educators Association, Volume 5 (2012): http://ahea.net/e-journal/volume-52012

Another form of cultural freedom is represented in the monument celebrating 125 years of Hungarian national sports which was erected by the Magyar Atlétikai Club (MAC) in 2000. Monuments marking an anniversary or a jubilee are a bit different from monuments to an event or a memorable person since, at least in this case, the object of commemoration still exists. The monument features the club's first contest with runners poised at the starting line with crowds standing around the arena. A written explanation under the relief tells us that this is a commemoration of a tradition which has been kept alive ever since. From historical sources we learn that the MAC had its first tournaments in vicinity to the Újépület on 6 May 1875 (Zeidler 2006, 32). This monument then relates to the place itself, but not to the prison in the way the monuments for the martyrs do. The text reads "Ép lélek cask edzett testben él" ("A healthy soul can only exist in a fit body."). The body can of course refer to any individual's body, but also to the Hungarian nation - as was the case with the four irredentist statues where each corner of Hungary was depicted by characters from these areas. The fitness then becomes both a moral imperative for the realization of a sound and complete Hungarian soul or spirit. One important point with this monument is the lack of differentiation of the periods between 1875 and 2000. This period is presented as a continuous one without looking at Trianon, Horthy, or Communism as representing any breaches.

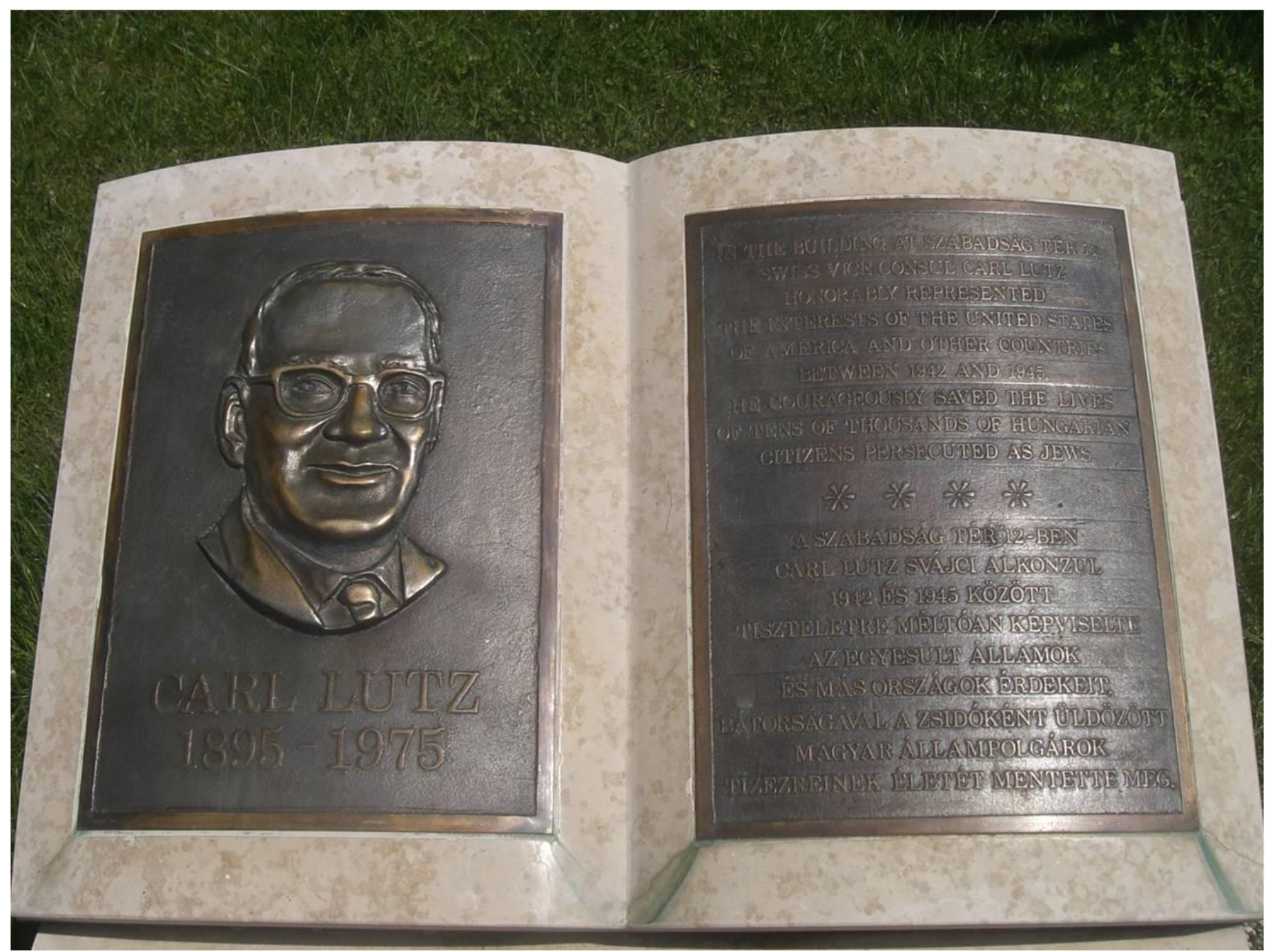

Fig. 17 In memory of Carl Lutz. Source: Photo by author. (C) Erik Thorstensen 
Erik Thorstensen. "The Places of Memory in a Square of Monuments: Conceptions of Past, Freedom and History at Szabadság Tér. AHEA: E-journal of the American Hungarian Educators Association, Volume 5 (2012): http://ahea.net/e-journal/volume-52012

The plaque in memory of Carl Lutz in front of the American Embassy differs from the other monuments celebrating or mourning Hungary's national past. From the reportage of the unveiling ceremony on 16 December, 2006, the American Embassy wrote:

Mayor of Budapest Gábor Demszky emphasized that, without the activity of Carl Lutz, Budapest would not be the multicultural metropolis that it has become, and added that Budapest is the only capital in Central Eastern Europe where a Jewish community of more than 100,000 has survived following the Holocaust. (Embassy of the United States, Hungary, Budapest, n.d.)

This monument adds a somewhat different idea to the Freedom Square with an understanding of freedom which is rather cosmopolitan and thus challenges the hegemony of nationalist thinking which can be deduced from its narratives about the past. According the logic inherent in the monument to Carl Lutz, Jews are part of Budapest's city life. Furthermore, by placing the Carl Lutz monument on the Freedom Square sends a message that ethnic and cultural diversity is liberating - both for the individual and the collective. Whether or not the Jews have been seen as an integral part of the Hungarian community is not the topic here, but suffice it to mention that the topic is complex and that historians like Paul Lendvai certainly are ambiguous on the topic. In the late nineteenth century there were blood libel cases in Hungary, and with the passing of the so called Numerus clausus act in 1920, Hungary was the first country to introduce restrictions on Jews entering the University. In addition, there is ample evidence of a mono-cultural ideal which can be illustrated by the fact that Hungarians seem proud that most Hungarian Jews spoke Hungarian and not Yiddish (Lendvai 2003). A more pragmatic reason for the Carl Lutz, monument's placement in Szabadság tér is that his offices were in fact located there, and he cooperated with Zionist activists from his offices (Rozett 1998, 144).

Such a symbolic interpretation needs to be seen in relation to the contemporary political reality. And in this case, it seems certain that the presence of the Carl Lutz' plaque does not signify a more open and inclusive attitude towards the past, present, and future composition of Hungarian society. According to Magdalena Marsovszky, in 2007 there was a large rally on Szabadság tér on the National holiday on 23 October in commemoration of the 1956 uprising. During this rally openly anti-Semitic speeches were held (Marsovszky 2010, 53-55). Anti-Semitism has been a constant presence in Hungarian political life since the playwright and spokesperson for the extreme right wing of the Hungarian Democratic Forum, István Csurka, published anti-Semitic conspiracy theories in August 1992 (Lendvai 2012, 45).

It seems obvious that the different symbols presently embodied by Szabadság tér clear indications of an unstable political community - an interpretation that is supported by the very existence of the Magyar Garda and the success of its political faction, Jobbik, that obtained 16,7 \% in the 2010 parliamentary elections (CIA 2010). 
Erik Thorstensen. "The Places of Memory in a Square of Monuments: Conceptions of Past, Freedom and History at Szabadság Tér. AHEA: E-journal of the American Hungarian Educators Association, Volume 5 (2012): http://ahea.net/e-journal/volume-52012

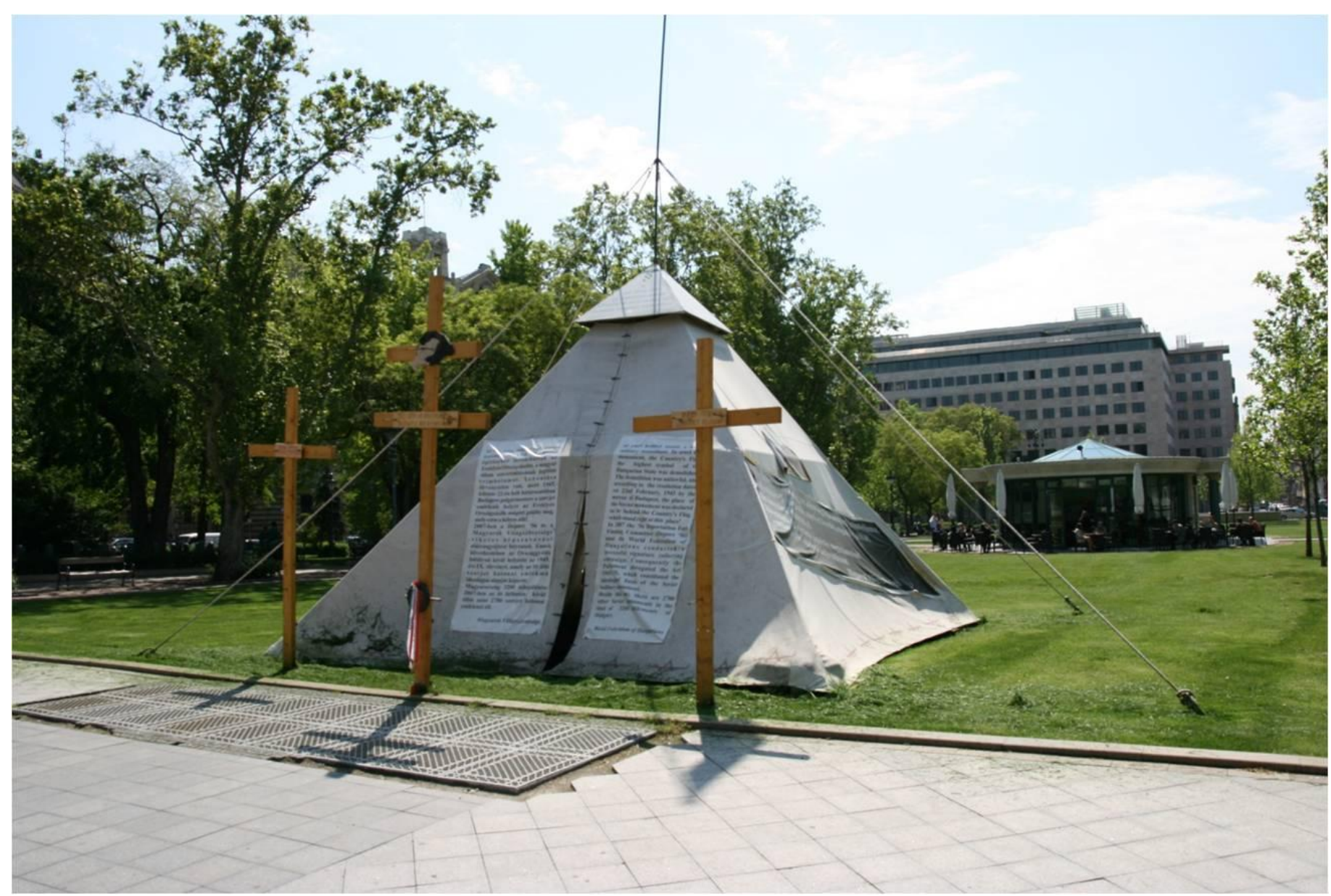

Fig. 18 Temporary Monument to re-erect the Irredentist monument I. Source: Photo by author. (C) Erik Thorstensen.

When I entered Szabadság tér in 2008 I was immediately taken by the temporary tent-and-3-crosses monument. The writing on the tent walls called for the re-erection of the Irredentist monument (1921/28) that was taken down in 1945. The tent-monument itself was erected by the World Federation of Hungarians, an organization whose main scope seems to be the revocation of the Treaty of Trianon. The World Federation of Hungarians was established in 1938 during the Second World Congress of Hungarians (Patrubány 2009). Both Jobbik and the neo-fascist Magyar Garda also has such a revocation as an aim (Moreau, 132). From 2000 the World Federation of Hungarians have been a driving force in establishing Hungarian citizenship for ethnic Hungarians outside of the state of Hungary's borders (Kovács 2005). They achieved a referendum on the issue, with the support of Fidesz, that took place on 5 December 2004, but the proposition was rejected (Lendvai 2012, 124). In May 2010 the Orbán government decided to offer Hungarian citizenship to Magyars in neighboring states (Lendvai 2012, 128). The issue of dual citizenship has been included in the new constitution that entered into effect on 1 January 2012. 
Erik Thorstensen. "The Places of Memory in a Square of Monuments: Conceptions of Past, Freedom and History at Szabadság Tér. AHEA: E-journal of the American Hungarian Educators Association, Volume 5 (2012): http://ahea.net/e-journal/volume-52012

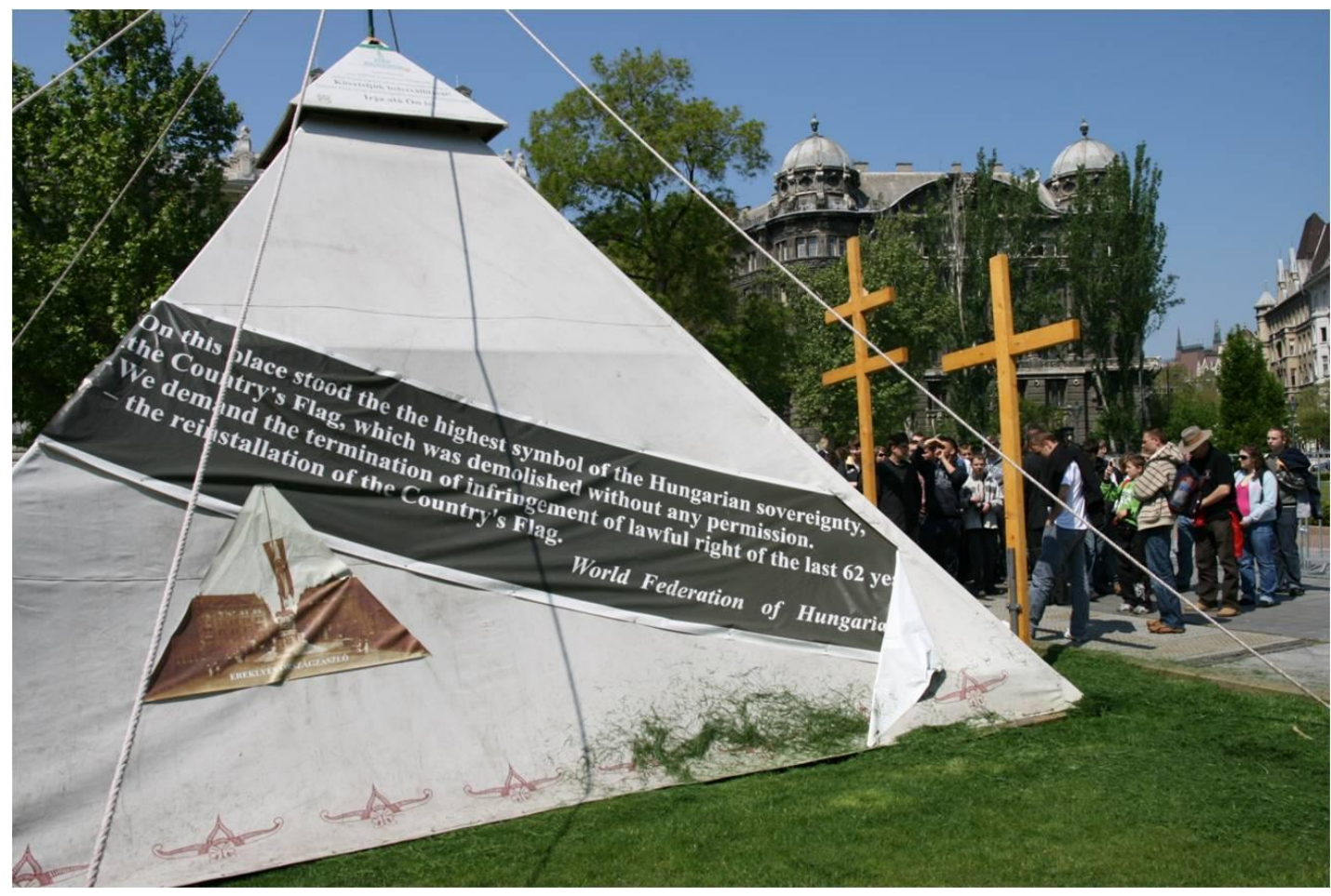

Fig. 19 Temporary Monument to re-erect the Irredentist monument II. Source: Photo by author. (C) Erik Thorstensen.

As we can read on the tent, there are clear political demands related to this new irredentist monument. It might seem improper of me to call it an irredentist monument, but given the three crosses with the picture of what some call pre-Trianon Hungary, it is also a call for Greater Hungary.

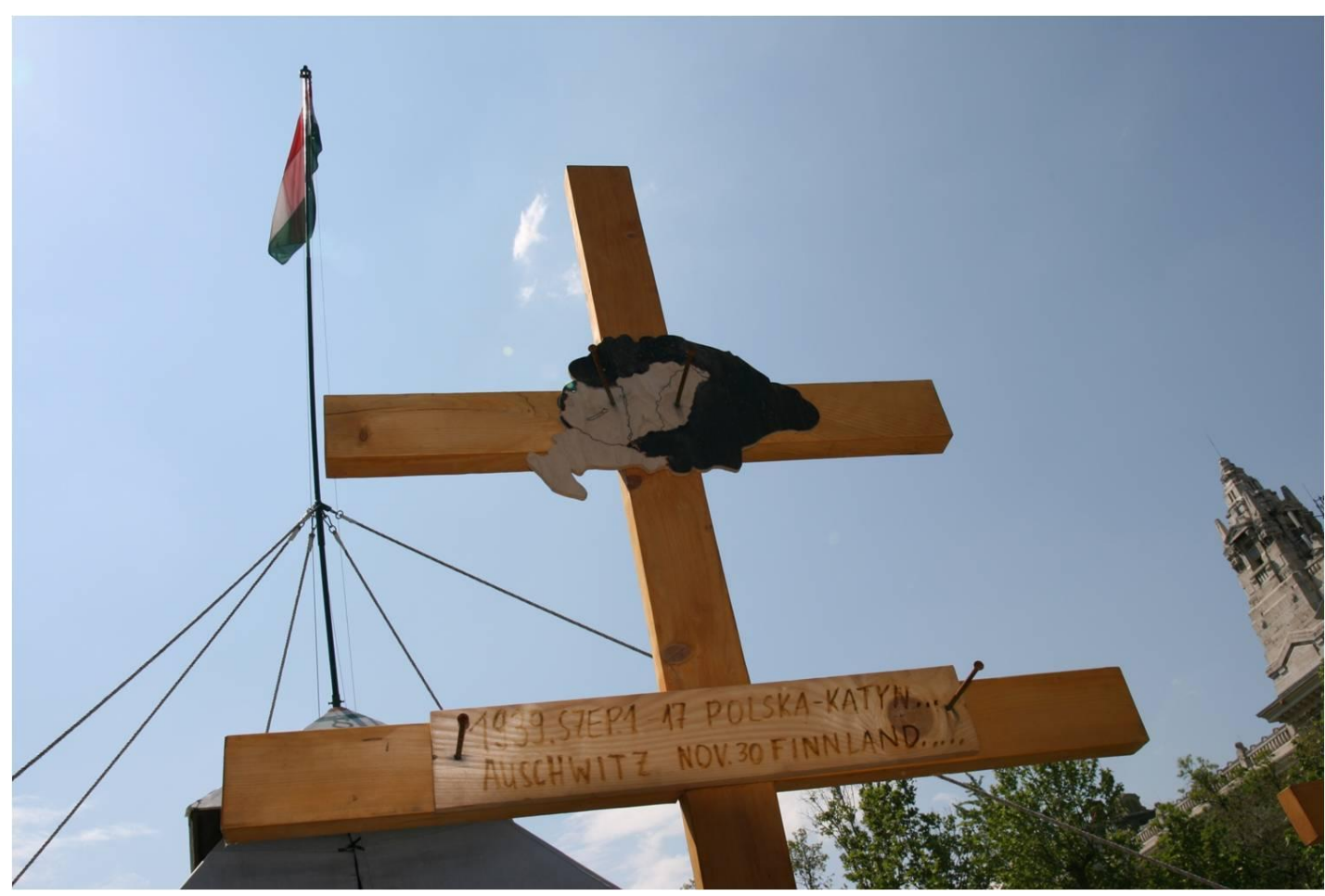

Fig. 20 Temporary Monument to re-erect the Irredentist monument III. Source: Photo by author. (c) Erik Thorstensen. 
Erik Thorstensen. "The Places of Memory in a Square of Monuments: Conceptions of Past, Freedom and History at Szabadság Tér. AHEA: E-journal of the American Hungarian Educators Association, Volume 5 (2012): http://ahea.net/e-journal/volume-52012

The crosses are a symbol, which tells us rather unequivocally that Hungary has been crucified. This interpretation relies on the map, which is pinned to the cross, as well as the text written on it. According to the Hungarian historian Miklos Zeidler, the parallel between the crucified Christ and Hungary was a commonplace in interwar irredentist propaganda (Zeidler 2002, 72). The crucified Jesus did rise - as shall Greater Hungary - but judging by the monuments on from the Square I visited in 2008, it seems that the old irredentist monument must be re-erected before this Greater Hungary shall rise again. This claim is not as farfetched as it might seem. Only ten years after the monument of the naked woman representing the grieving Hungarians (fig. 9) was built in 1928, Horthy raised the flag to full-mast. As I explained above, the moment the flag reached the top of the pole, the pole and the whole complex became a monument to victory and the claims to re-erect the irredentist complex cannot be understood without taking this into consideration.

The dates and places written on the cross in the middle, "1939 Szep1 17 Polska Katyn/Auschwitz Nov 30 Finnland", refer to the Soviet invasion of Poland according to the Molotov-Ribbentrop Pact and the 1940 massacre in Katyn of Polish military by the Red Army. Finland was attacked by the Red Army on 30 November 1939. The inclusion of "Auschwitz" puzzles me, but I believe that "Auschwitz" is included to have three events that correspond to the three crosses. "Auschwitz" has taken on a meaning that is larger than the camp itself and the atrocities there and now often metonymically refers to the whole of the Holocaust understood as a brutal massacre and crime against mankind.

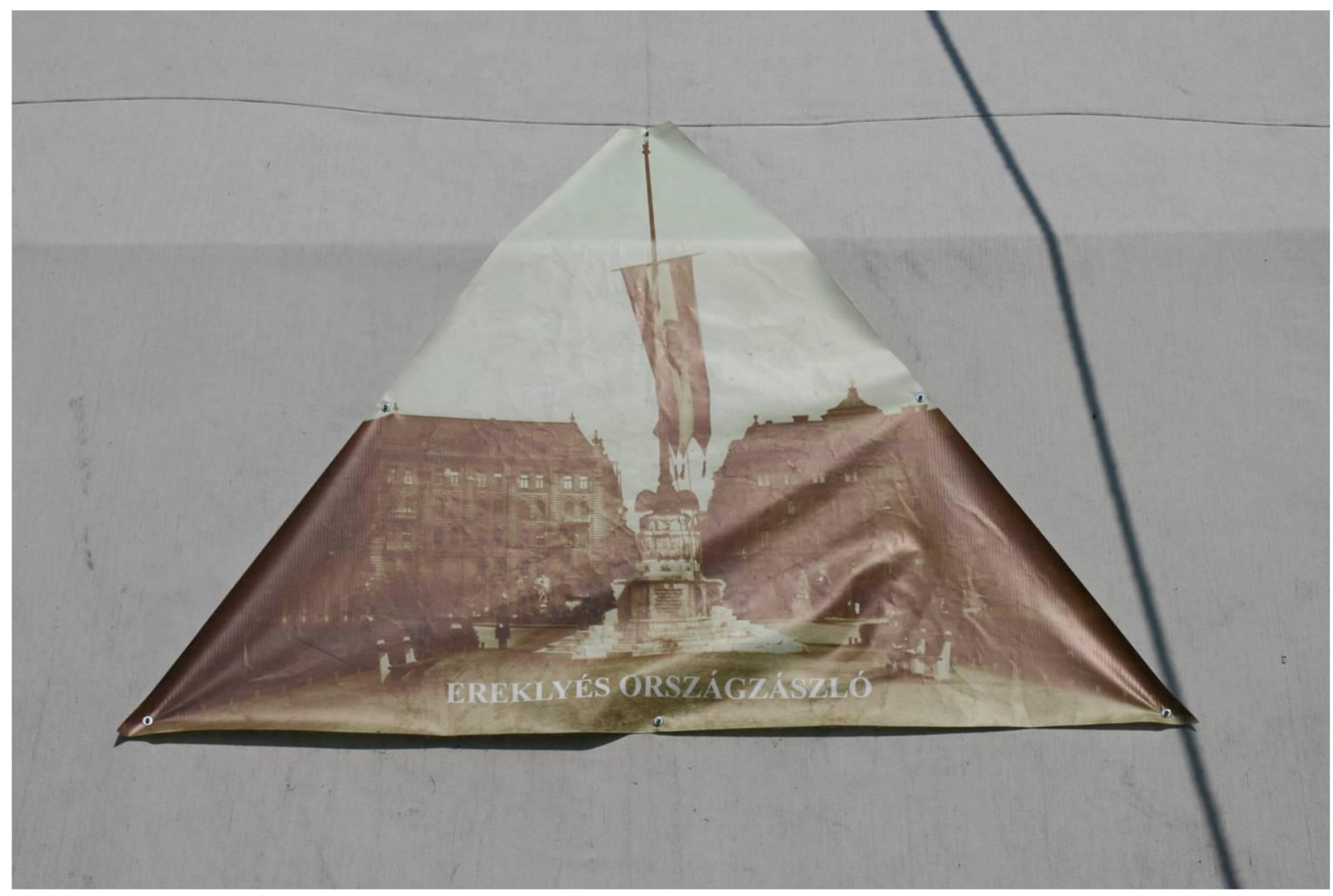

Fig. 21 Temporary Monument to re-erect the Irredentist monument IV - detail. Source: Photo by author. (C) Erik Thorstensen. 
Erik Thorstensen. "The Places of Memory in a Square of Monuments: Conceptions of Past, Freedom and History at Szabadság Tér. AHEA: E-journal of the American Hungarian Educators Association, Volume 5 (2012): http://ahea.net/e-journal/volume-52012

The shape of the tent-like structure of this 2008 irredentist monument, as well as its materiality, differ significantly from its "enemy," the Soviet Liberation monument's obelisk in stone. Both the form and the fabric seem to say that it will not be there forever and that there will come another monument and fulfill its function and tell its story. Thus this temporary monument in 2008 functions like a John the Baptist before Christ - the one who paved the way and prepared for the true message.

Given the multiplicity of freedom ideas that are presented at Szabadság tér, anything can happen, as I experienced the summer of 2011 when a 7-foot bronze statue of Ronald Reagan was unveiled on anniversary of his $100^{\text {th }}$ birthday on 29 June 2011 (USEmbassyBudapest 2011).

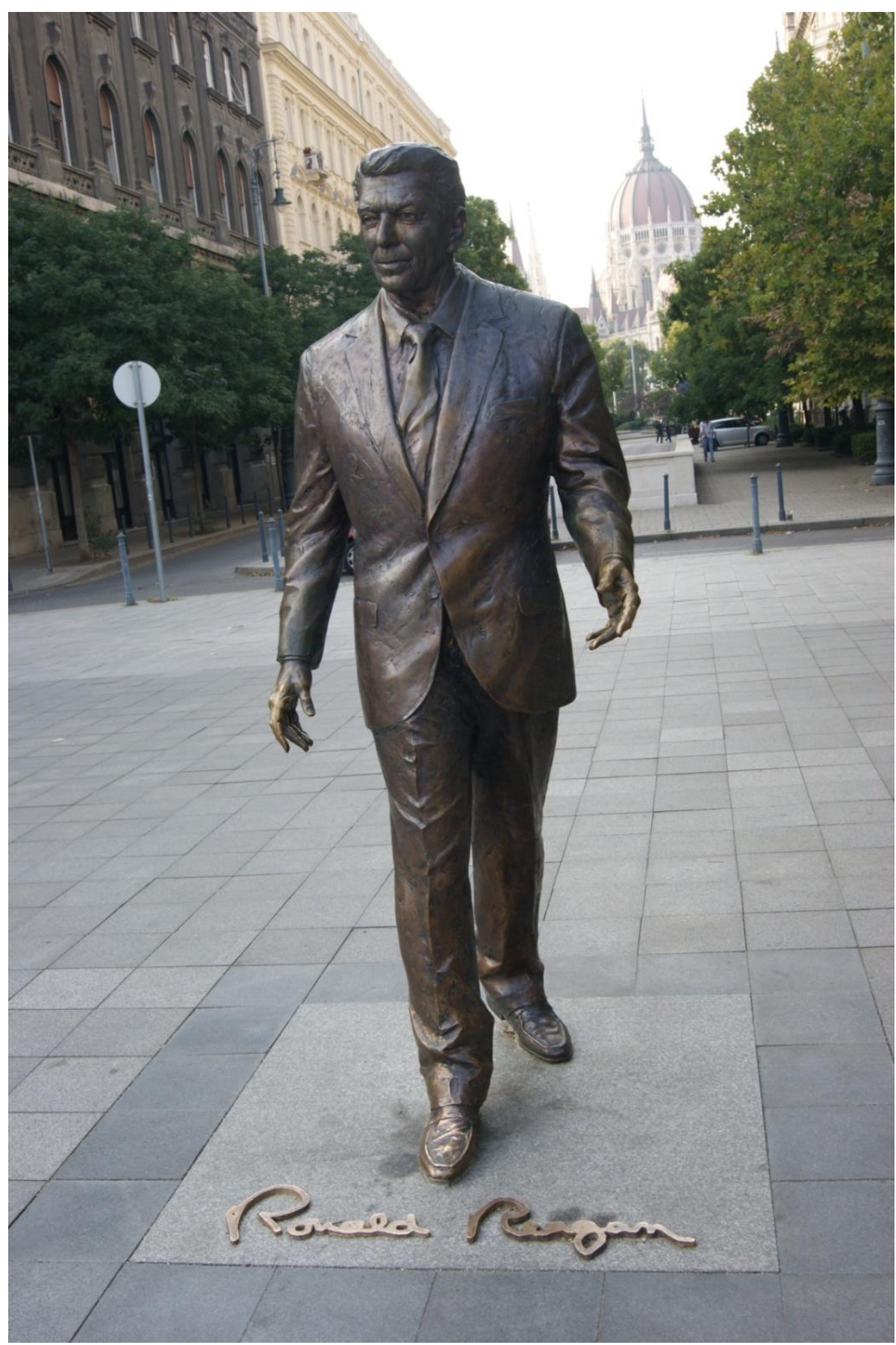

Fig. 22 Ronald Reagan statue. Source: Photo by Cecilie Endresen. @ C Cecilie Endresen. 
Erik Thorstensen. "The Places of Memory in a Square of Monuments: Conceptions of Past, Freedom and History at Szabadság Tér. AHEA: E-journal of the American Hungarian Educators Association, Volume 5 (2012): http://ahea.net/e-journal/volume-52012

The Reagan statue must be understood within the context of creating a canon of Hungary's past. In this national narrative the American president is included and celebrated for his anti-Communist politics: he called the Soviet Union an evil empire and challenged Gorbachev to "tear down this [the Berlin] wall". Ronald Reagan might have been causally efficient in bringing democracy and national sovereignty to Communist Europe, but by placing Reagan in Szabadság tér he becomes similar to Bandholtz in securing Hungarian national independence. Furthermore, this statue increases the symbolic tension at the square since it must be understood as a comment to the Communist obelisk. The Reagan statue negates Communism's claims to be liberating and thus affirms the irredentist story. Such explicit monuments as both the Reagan statue and the Communist obelisk tell stories that are either all black or all white - no shades of grey are allowed and History belongs to the victor. In line with Paul Lendvai's (2012) claims that Hungary has avoided to have a judicial or political process where wrongdoings and repressions in the Communist period were addressed, it is also possible to interpret the statue as creating a link between Hungary in the 1980s and USA in the 1980s. This statue can then be understood as an attempt by the Hungarian nation to reaffirm its own role in bringing about the changes that led to Hungary again becoming a state based on selfdetermination and freedom.

In order to analyze more systematically the monuments at the Szabadság tér, I will use the distinction between "canon" and "archive", as I discussed above. Canon can then be understood as the contemporary collective consensus about the significance of the past, while archive is both the past collective consensus about what ought to be significant for the future and the contemporary collective toleration of deviances in the past.

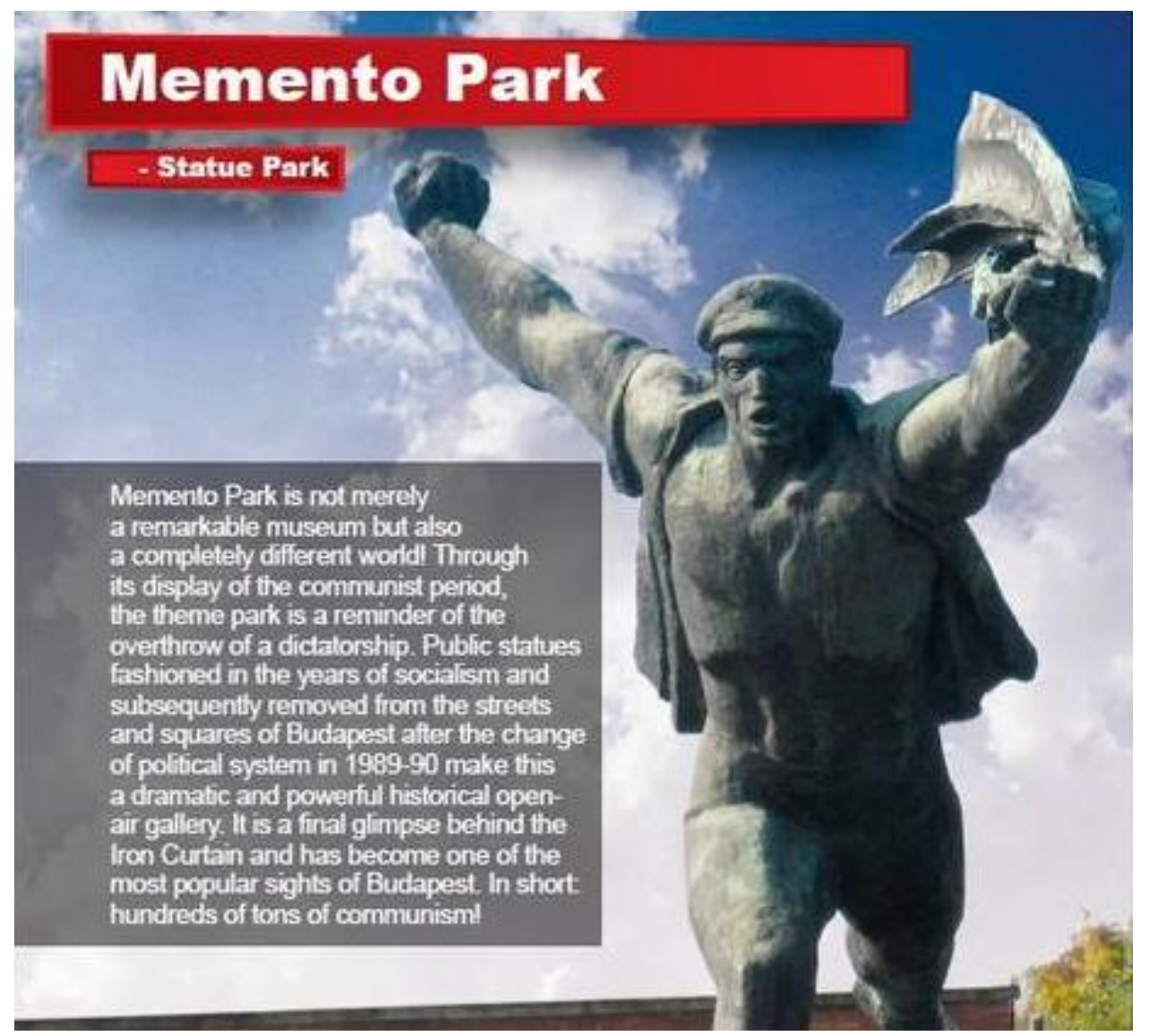

Fig. 23 From the brochure of the Memento Park. Source: The Memento Park. 
Erik Thorstensen. "The Places of Memory in a Square of Monuments: Conceptions of Past, Freedom and History at Szabadság Tér. AHEA: E-journal of the American Hungarian Educators Association, Volume 5 (2012): http://ahea.net/e-journal/volume-52012

In view of the well-established and uncontroversial Memento Park on the outskirts of Budapest, where many of the statues from the Communist era are kept, there seems to be a collective consensus about the historical fact that the Communist period is a part of Hungarian history, but given the remoteness of the Statue Park, I would classify it and the Communist period with it as part of an Hungarian archive.

The existence of this park shows that Communism is accepted in its archival form. Given presence of the memorials from the Horthy era on Szabadság tér in Budapest's city center these have the double meaning of both pointing to the national uprising in 1848/49, but also to the period of the authoritarian Hungary since they were established during the Horthy regime. In this respect it seems to indicate that their material presence - the archive - also encompasses the Horthy years. Furthermore the Horthy years have until recently not been addressed as a "canonical" period. One exception to this has been the Holocaust Museum where the discrimination against Jews under Horthy is an issue. Whereas the House of Terror, a house presenting Hungary and Hungarians as victims, the Horthy years are not directly addressed in terms of authoritarian rule and extreme nationalism, but are presented more as a given fact, i.e. as archive, and a contrast to the subjugation of Hungary under foreign ideologies and powers.

When introducing the distinction between "canon" and "archive", a pattern emerges where the only period that is canonized as part of Hungarian collective memory is the period 1848/49, while the years from 1867 to 1919 are not remembered - with the curious exception of the sports federation. With Harry Bandholtz there is a small opening of canonization of a few months of 1919 after Bela Kun and before Admiral Horthy.

The Soviet liberation monument is according to The Fundamental Law of Hungary, the Hungarian constitution that entered into effect on 1 January 2012, from a period when there was no Hungarian selfdetermination. This self-determination was "lost on the nineteenth day of March 1944" and the period lasted to "the second day of May 1990" (The National Assembly of the Hungarian Republic 2011, 1). Here the period which lasted from the Nazi invasion in spring 1944 through to the end of the Communist era is depicted as a parenthesis in the national narrative. Such a clause points to a strong nationalistic framework which might aid the opponents of the Soviet liberation monument, and it is then likely to be removed. To reerect parts of or the whole irredentist monument complex will signify an inclusion of authoritarian and irredentist Hungary into the Hungarian canon.

Another indicator on the direction of Hungarian political culture is the decision to confer Hungarian citizenship to ethnic Hungarians outside of the Republic of Hungary (MTI 2011), which were another of the main issues for the World Federation of Hungarians - the constructors of the tent-monument. Not surprisingly, this decision has caused both anger and concern in neighboring Slovakia both because Slovakia sees this as a breach of earlier treaties and since Hungary unilaterally introduced such a law (BBC 2010). The Slovak concerns should also be understood in light of the Article $G$ in the new Constitution where the $2^{\text {nd }}$ paragraph reads: "(2) Hungary shall defend its citizens".

Meanwhile the struggle to remove the Soviet liberation monument continues. The present Mayor of Budapest, István Tarlós (FIDESZ), has opened up discussions through the Foreign Ministry with Russia to discuss the future of the monument (Bollobas 2011). It seems obvious from the comments Mayor Tarlós has made that he prefers to remove the monument, but on the other hand he "has no desire to be at the centre of a diplomatic incident". The installation of the Reagan statue should be understood as an ad hoc strategy to change the meaning of the square and the "Hungarian canon" since the Reagan statue negates the story told by the Soviet liberation monument. In June 2012, Foreign Minister Janos Martonyi denied that there are any plans or even talks with Russia concerning the removal of the Soviet memorial on Szabadsag tér (MTI 2012a).

Tarlós' strategy may be understood as steps towards removing the whole Communist archive from the cityscape of Budapest. This interpretation is strengthened by the recent decision by parliament to rearrange the whole of Kossuth tér, the Square in front of the Parliament building, and to restore it to its 1944 appearance. This would mean to remove all physical traces of Communism, even a statue of Lajos Kossuth himself, and to re-install a previous statue in its place (Dent 2011). To restore the Kossuth tér to its pre-1944 "glory" is not only an aesthetic but also a political gesture, and its vicinity to the parliament 
Erik Thorstensen. "The Places of Memory in a Square of Monuments: Conceptions of Past, Freedom and History at Szabadság Tér. AHEA: E-journal of the American Hungarian Educators Association, Volume 5 (2012): http://ahea.net/e-journal/volume-52012

building makes it symbolically important. As mentioned in the beginning of this article, the parliament building (Országház) is a massive Neo-Gothic monument to national freedom and democracy. Such changes at Kossuth tér will remove all archival traces between 1944 and 1990, and consequently to create a canon where this period did not exist. Hungarians will then be exempted from making any judgments regarding their own contributions to these regimes. This cleansing of history started in March 2012 at Kossuth tér, according to the so-called "Imre Steindl programme", named after the Országház' architect, and the appearance is changing with tremendous speed Ferenczi 2012). According to the Hungarian Government, the restoration of the pre-1944 Kossuth tér is linked to the "change of regime". It is difficult to take the Hungarian Government's arguments at face value since it is also removing the statue of Mihaly Karolyi, the prime minister after the democratic revolution of late 1918 and president of the republic from 11 January to 21 March 1919, from its location close to the Országház (MTI 2012b). It is difficult not to assess this as a further political initiative to remove all remnants that connote Hungarian subjugation.

The suggested remodeling of the museum structure in Budapest can also be seen in the perspective I have suggested here. These plans seem to include the creation of a new museum quarter in the areas around either the Városliget, Andrássy út, or the Nyugati railway station. This quarter would house the collections from the merged Hungarian National Gallery and the Museum of Fine Arts, the Ludwig Museum of Contemporary Arts, the Ethnography Museum, and a new Photography Museum (Williams 2012). The government commissioner for Budapest's new museum quarter explained the political logic behind the project in an interview with The Art Newspaper in 2011:

Our prime minister is particularly fond of unconventional solutions, because he is convinced that only new approaches will offer a way out of the crisis. So it fits in perfectly with the logic of this government to launch a cultural mega-project of such emblematic significance right in the middle of general budget cuts: one which, besides its intrinsic value, also expresses an extremely important symbolic message - it is even more important to build at a time when there is no belief that it is possible. (Unwin 2011)

The thoughts expressed here openly suggest that the remodeling of the city of Budapest are used as political tool in order to appease the population in a time of crises.

These changes in city space whereby all traces of Communism are demolished can be read into a discussion that has taken place on the cityscape of Budapest over the last five years. The political acceptance of the installation of the temporary monument to re-erect the irredentist monument at Szabadság tér is part of this struggle of national canonization. The political culture in Hungary now shows itself as embracing the Horthy-years and rejecting Communism. Memories of the communist period are not deemed worthy to preserve and likewise should not be permitted to "linger in latency". The official governmental strategies to wipe out all traces of the Hungary's Communist past are seen by Andras Gerö as "driven by cold political calculation" since nothing stops the Orbán government in obtaining state ownership in key industries (Dunai 2012). 
Erik Thorstensen. "The Places of Memory in a Square of Monuments: Conceptions of Past, Freedom and History at Szabadság Tér. AHEA: E-journal of the American Hungarian Educators Association, Volume 5 (2012): http://ahea.net/e-journal/volume-52012

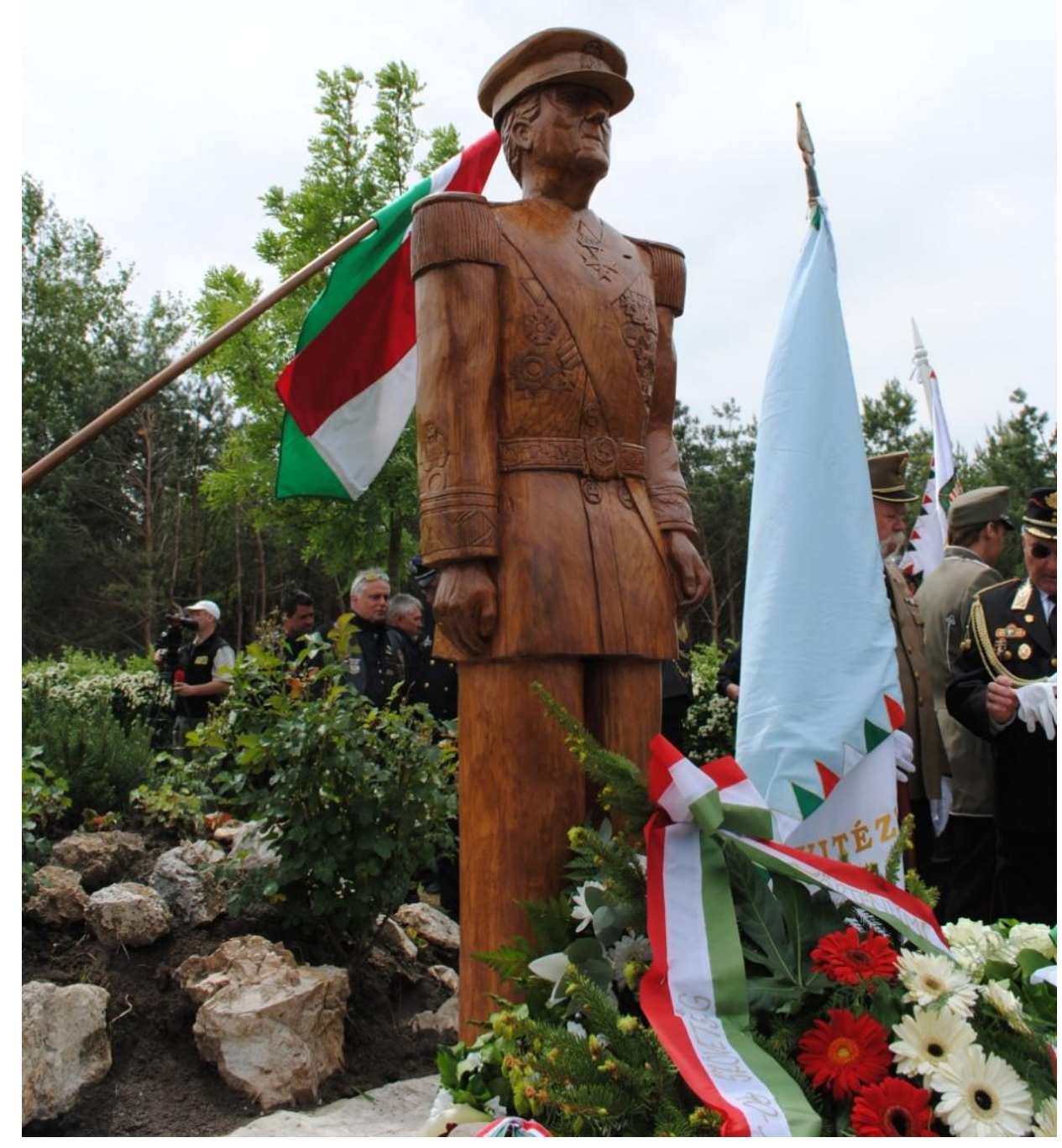

Fig. 24 Horthy statue in wood at Kereki (Nemzeti Bulvár 2012). Source: Nemzeti Bulvár. http://www.nemzetibulvar.hu/wp-content/uploads/2012/05/horthy-szobor-avatas-kereki-201x300.jpg.

Towards the end of the writing of this article, there have been two unveiling events of Horthy statues in Hungary. In Kereki on 15 March 2012 , and in Csókakő on 16 June 2012 (A.L.B. 2012, hir24web 2012, JewishNewsOne 2012, and MTI 2012 c). At both occasions, the Hungarian Guard was present and fascist symbols prevalent. 
Erik Thorstensen. "The Places of Memory in a Square of Monuments: Conceptions of Past, Freedom and History at Szabadság Tér. AHEA: E-journal of the American Hungarian Educators Association, Volume 5 (2012): http://ahea.net/e-journal/volume-52012

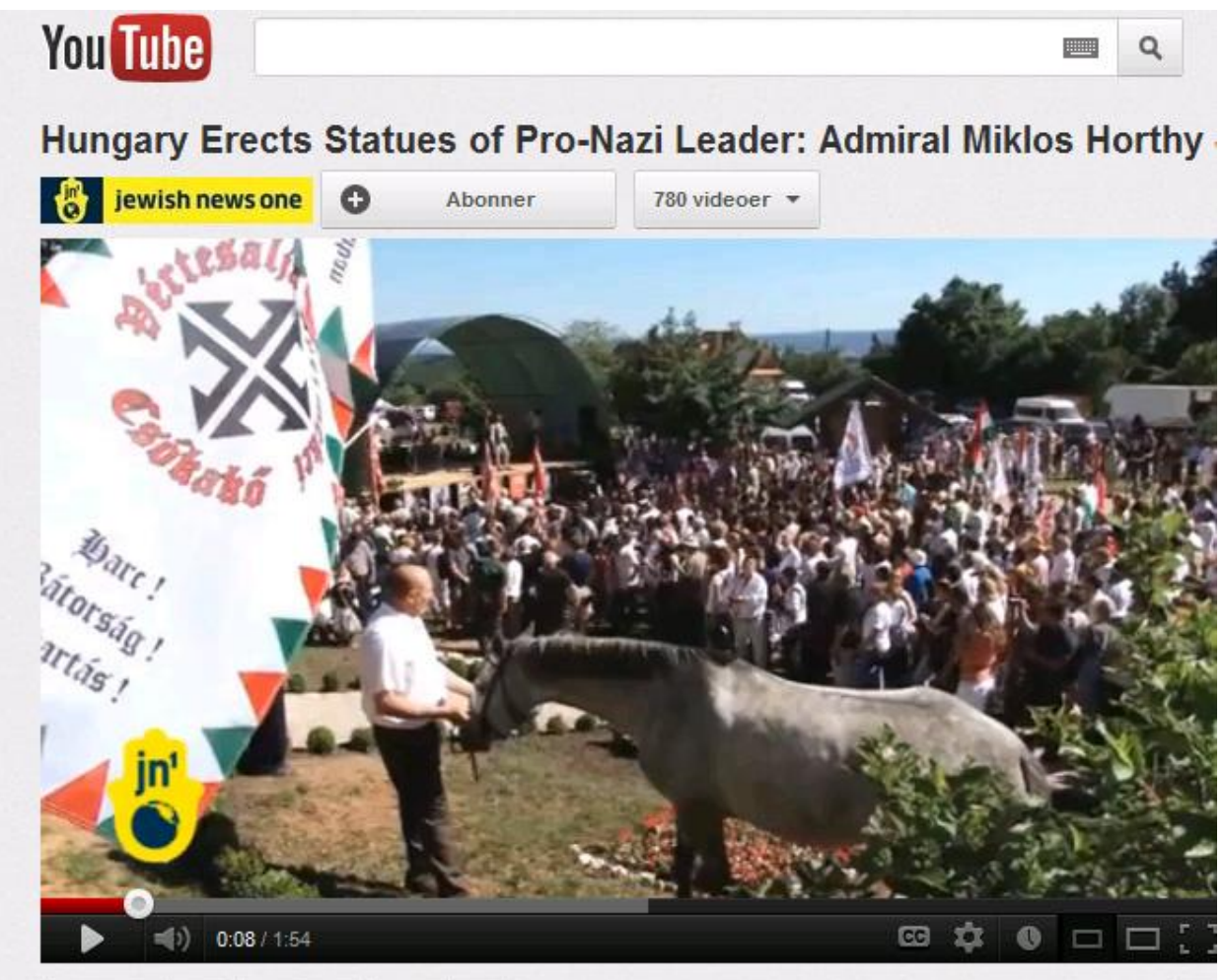

Fig. 25 Csókakő

Source: Youtube. www.youtube.com/watch?v=SHuBvpsyp1A, (JewishNewsOne 2012).

With the removal of all traces from the non-Horthy years from the cityscape of Budapest and the installation of statues of him in the countryside, the hegemonic Hungarian politics of memory reflects and adds to a political landscape that is drifting both into an idealized past and further and further away from democracy.

\section{Works Cited}

Adriányi, Gabriel. 1993. "MINDSZENTY, József." Biographisch-Bibliographischen Kirchenlexikons: <http://www.bautz.de/bbkl/m/mindszenty.shtml>.

Ahonen, Sirkka. 2011. "Representations of Victims and Guilty in Public History: The Case of the Finnish Civil War in 1918." Historicizing the Uses of the Past. Eds. Helle Bjerg, Claudia Lenz and Erik Thorstensen. Bielefeld: Transcript Verlag: 27-44.

A.L.B. 2012. "Does Hungary have a new hero?" The Economist. 18 June 2012:

<http://www.economist.com/blogs/easternapproaches/2012/06/hungarian-history>.

Assmann, Aleida. 2010. "Re-Framing Memory: Between Individual and Collective Forms of Constructing the Past." Performing the Past: Memory, History, and Identity in Modern Europe. Eds. Karin Tilmans, Frank van Vree and Jay Winter. Amsterdam: Amsterdam University Press, 35-50.

Atkinson David, and Denis Cosgrove. 1998. "Urban Rhetoric and Embodied Identities: City, Nation, and Empire at the Vittorio Emanuele II Monument in Rome, 1870-1945." Annals of the Association of American Geographers 88.1: 28-49.

BBC. 2010. "Slovaks retaliate over Hungarian citizenship law." BBC News Europe. 26 May 2010: 〈http://www.bbc.co.uk/news/10166610>. 
Erik Thorstensen. "The Places of Memory in a Square of Monuments: Conceptions of Past, Freedom and History at Szabadság Tér. AHEA: E-journal of the American Hungarian Educators Association, Volume 5 (2012): http://ahea.net/e-journal/volume-52012

Bollobas, Mark. 2011. "Tarlós refutes claims that the Soviet memorial on Szabadság Tér will be moved." Hirado.hu. 23 March 2011:

<http://www.hirado.hu/Hirek/2011/03/23/15/Tarlos_refutes_claims_that_the_Soviet_memorial_on.a $\mathrm{spx}>$.

Budapest Galéria. "V.kerület." n.d.: Budapest Galéria <http://www.budapestgaleria.hu/index.php?akt_menu=130>.

Caples, Matthew. 2005. "Et In Hungária Ego: Trianon, Revisionism and The Journal Magyar Szemle (1927-1944)." Hungarian Studies 19.1: 51-104, available on http://epa.oszk.hu/01400/01462/00033/pdf/051-104.pdf.

CIA. 2010. "Hungary." The World Factbook. 17 November 2010: <https://www.cia.gov/library/publications/the-world-factbook/geos/hu.html>.

Dent, Bob. 2011. "Statues of Liberty." Budapest Times. 1 November 2011:

<http://www.budapesttimes.hu/index.php?option=com_content\&task=view\&id=20806\&Itemid=219>

Dengizik1. 2011. "Tündérszép Budapest 1938 - Budapest in color /1938/- rarity in the history of the film." YouTube. 21 February 2011: <http://www.youtube.com/watch?v=51qtsyxvZ64>.

Dunai, Marton. 2012. "Hungary's Orban seeks to wipe out communist past." Reuters. 1 February: <http://www.reuters.com/article/2012/02/01/uk-hungary-communismidUSLNE81001C20120201>.

Egykor.hu. 2010. "Újépület Szabadság tér." 2 February 2010: <http://egykor.hu/budapest-vkerulet/ujepulet-szabadsag-ter/519> .

Embassy of the United States, Hungary, Budapest. "CARL LUTZ MEMORIAL." n.d.: $<$ http://hungary.usembassy.gov/lutz.html>.

Ferenczi, Krisztina. 2012. "Egy nap alatt lejátszották a Kossuth téri fairtást." Népszabadságonline. 19 March 2012: <http://nol.hu/belfold/egy_nap_alatt_lejatszottak_a_kossuth_teri_fairtast>.

Filmhíradók online (a). "Leleplezték a Magyar Fájdalom szobrát, Rothermere lord ajándékát." n.d.: <http://filmhiradok.nava.hu/watch.php?id=352>

Filmhíradók online (b). "A Szabadság-téren felvonták az eddig félárbocra eresztett országzászlót." N.d.: <http://filmhiradok.nava.hu/watch.php?id=3053>.

Foucault, Michel. 1997. "Il faut defendere la société”. Cours au Collège du France. 1976, Paris, Seuil/ Gallimard.

Gerö, András. 1990. Heroes' Square Budapest: Hungary's History in Stone and Bronze. Trans. Christina Molinari, Budapest, Corvina.

Gerő, András. 1997. The Hungarian Parliament (1867-1918). A Mirage of Power, Boulder, CO: Social Science Monographs.

Gerő, András. 2006. Imagined Histories. Chapters from Nineteenth and Twentieth Century Hungarian Symbolic Politics. Trans. Mario D. Fenyo, Boulder CO: Social Science Monographs Center for Hungarian Studies and Publications Inc.

Hall, Peter. 2002. Cities of Tomorrow. 3rd ed. Malden MA \& Oxford: Blackwell Publishing.

Hedrick, Charles W. Jr. 2000. History and Silence: Purge and Rehabilitation of Memory in Late Antiquity, Austin TX, University of Texas Press.

hir24web. 2012. "Horthy-szobrot avattak Kerekiben." YouTube. 13 May 2012: <http://www.youtube.com/watch?v=6INjQfqeXMA>.

The Hungarian Government. 2012. "Kossuth tér - one of Budapest's most important city squares - is being returned to its former glory." Kormanu.hu. 13 March 2012: <http://www.kormany.hu/en/news/kossuth-ter-one-of-budapest-s-most-important-city-squares-isbeing-returned-to-its-former-glory>.

Hunt, Tristram. 2004. Building Jerusalem: The Rise and Fall of the Victorian City. London: Weidenfeld \& Nicholson. 
Erik Thorstensen. "The Places of Memory in a Square of Monuments: Conceptions of Past, Freedom and History at Szabadság Tér. AHEA: E-journal of the American Hungarian Educators Association, Volume 5 (2012): http://ahea.net/e-journal/volume-52012

JewishNewsOne. 2012. "Hungary Erects Statues of Pro-Nazi Leader: Admiral Miklos Horthy Joined Axis, Aided Holocaust." YouTube. 20 June 2012. $<$ http://www.youtube.com/watch?v=SHuBvpsyp1A $>$.

Judt, Toby. 2005. Postwar. A History of Europe since 1945. New York: The Penguin Press.

Kovács, Mária M. 2005. "The Politics of Non-resident Dual Citizenship in Hungary”. Regio. Minorities, Politics, Society vol 8. 2005: 50-72.

Lendvai, Paul. 2003. The Hungarians: A Thousand Years of Victory in Defeat. Princeton New ersey: Princeton University Press.

Lendvai, Paul. 2012. Hungary: Between Democracy and Authoritarianism. Translated by Keith Chester. London: Hurst \& Company.

Mann, Michael. 2004. Fascists. Cambridge, Cambridge University Press.

Marsovszky, Magdalena. 2010. "Antisemitism in Hungary: How an Ideology threatens to Become violent." Antisemitism in Eastern Europe: History and Present in Comparison. Eds. HansChristian Petersen and Samuel Salzborn. Frankfurt am Main, Berlin, Bern, Bruxelles, New York, Oxford, Wien: Peter Lang: 47-66.

Moreau, Patrick. 2011. "The Victorious Parties - Unity in Diversity." The Extreme Right in Europe: Current Trends and Perspectives. Eds. Uwe Backes and Patrick Moreau. Göttingen: Vandenhoeck \& Ruprecht GmbH \& Co: 75-148.

MTI. 2011. "Orbán calls dual citizenship historic achievement." Politics.hu. 24 November 2011: < http://www.politics.hu/20111124/orban-calls-dual-citizenship-historic-achievement>.

MTI .2012 (a). "Foreign Minister says no plans to remove Soviet memorials in Hungary." Politics.hu. 27 June 2012: <www.politics.hu/20120627/foreign-minister-says-no-plans-to-removesoviet-memorials-in-hungary>.

MTI. 2012 (b). "Károlyi statue removed from Parliament despite Socialist 'guards'." Politics.hu. 29 March 2012: <www.politics.hu/20120329/karolyi-statue-removed-from-parliamentdespite-socialist-guards>.

MTI 2012 (c). "West Hungarian village erects Horthy memorial." Politics.hu. 14 May 2012.: <http://www.politics.hu/20120514/west-hungary-village-erects-horthy-memorial>.

The National Assembly of the Hungarian Republic. 2011. THE FUNDAMENTAL LAW OF HUNGARY, voted 25 April 2011, enters into effect 1 January 2012, available on http://www.kormany.hu/download/4/c3/30000/THE\%20FUNDAMENTAL\%20LAW\%20OF\%20H UNGARY.pdf.

Neale, C. W. and S. Bozsik. 2001. "How the Hungarian State-owned Banks were Privatised." Post-Communist Economies 13.2: 147-169.

Nemzeti Bulvár. 2012. "Vörös festékkel készül leönteni Horthy most felavatott szobrát a hírhedt ügyvéd." Nemzeti Bulvár. 15 May 2012: <http://www.nemzetibulvar.hu/voros-festekkelkeszul-leonteni-horthy-most-felavatott-szobrat-a-hirhedt-ugyved>.

Nora, Pierre. 1989. "Between Memory and History: Les Lieux de Memoire." Representations 26: 7-24.

Palonen, Emilia. 2002. "Postcommunist Histories in Budapest: The Cult of Great Men in Spring 2002." The Contours of Legitimacy in Central Europe: New Approaches in Graduate Studies Postgraduate Conference, St. Antony's College, Oxford, 24-26 May, available on http://users.ox.ac.uk/ oaces/conference/papers/Emilia_Palonen.pdf.

Palonen, Emilia. 2006. Reading Budapest: Political Polarisation in Contemporary Hungary. $\mathrm{PhD}$ Thesis, Department of Government at the University of Essex, available on http://polemics.files.wordpress.com/2007/06/emilia_palonen_phd_thesis2006.pdf.

Palonen, Emilia. 2008. "The city-text in post-communist Budapest: street names, memorials, and the politics of commemoration." GeoJournal 73: 219-230.

Patrubány, Miklós. 2009. "Justice for Europe! The Hungarian Question can no longer be postponed." Magyarok Világszövetsége. 1-2May, 2009: <http://www.mvsz.hu/>. 
Erik Thorstensen. "The Places of Memory in a Square of Monuments: Conceptions of Past, Freedom and History at Szabadság Tér. AHEA: E-journal of the American Hungarian Educators Association, Volume 5 (2012): http://ahea.net/e-journal/volume-52012

Rozett, Robert. 1998. "International Intervention: The Role of Diplomats in Attempts to Rescue Jews in Hungary." The Nazis' Last Victims: The Holocaust in Hungary. Ed. Randolph L.

Braham. Detroit Michigan: Wayne State University Press: 137-152.

Savage, Kirk. 1994. "The Politics of Memory: Black Emancipation and the Civil War Monument." Commemorations. The Politics of National Identities. Ed. John R. Gillis. Princeton NJ: Princeton University Press: 127-49.

Székely, Júlia. 2009. "A City of (Anti-)Heroes. The Politics of Public Art in Hungary." MA Thesis, Department of Sociology and Social Anthropology at the Central European University, Budapest.

Szoborlap. "Magyar fájdalom szobra." n.d.: <http://www.szoborlap.hu/13981_magyar_fajdalom_szobra_budapest_emile_guillaume_1932.html?1 $\& n r=1>$.

Therborn, Göran. 2006. "Eastern Drama: Capitals of Eastern Europe, 1830s-2006: An Introductory Overview." International Review of Sociology / Revue Internationale de Sociologie, 16.2: 209-242.

Ungváry, Krisztián. 2003. Battle for Budapest: One Hundred Days in World War II. Trans. Ladislaus Löb. London: I.B.Tauris \& Co Ltd.

Unwin, Richard. 2011. "Budapest 'mega-project' to defy the downturn." The Art Newspaper. Issue 229/2011.

US Embassy Budapest. 2011. "Ronald Reagan szobrának felavatása Budapesten.” YouTube. 1 July 2011: 〈http://www.youtube.com/watch?v=i12DLTO-uDs>.

Williams, Bénédicte. 2012. "Cabinet remakes history. City Park gets nod for Museum Quarter showcase." Budapest Times. 12 July 2012: <http://www.budapesttimes.hu/2012/07/14/cabinetremakes-history>.

Young, James E. 1992. "The Counter-Monument: Memory against Itself in Germany Today." Critical Inquiry 18.2: 267-296.

Zeidler, Miklós. 2002. "Irredentism in Everyday Life in Hungary during the Inter-war Period." Regio. Minorities, Politics, Society 12.1: 71-88.

Zeidler, Miklos. 2006. "English Influences on Modern Sport in Hungary Part 2." The Hungarian Quarterly 182: 27-47.

Zsolt, Zétényi. 2006. A Szabadság téri szovjet hösi emlékmü ügye 2006-ban. Jogi és politológiai szakvélemény. (Tények- követelmények- lehetőségek- teendők). Budapest, Nemzeti Jogvédő Alapítvány, available on http://www.nemzetijogvedo.hu/sajtotaj/Szabadsag_teri_tanulmany.doc. 